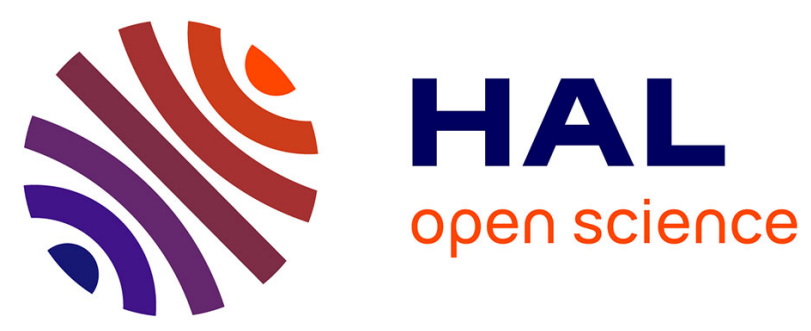

\title{
Chemical migration in drinking water stored in polyethylene terephthalate (PET) bottles: a source of controversy reviewed
}

Cristina Bach, Xavier Dauchy, Marie-Christine Chagnon, Serge Etienne

\section{To cite this version:}

Cristina Bach, Xavier Dauchy, Marie-Christine Chagnon, Serge Etienne. Chemical migration in drinking water stored in polyethylene terephthalate (PET) bottles: a source of controversy reviewed. Water Research, 2012, 46 (3), pp. 571-583. 10.1016/j.watres.2011.11.062 . hal-00683918

\section{HAL Id: hal-00683918 https://hal.science/hal-00683918}

Submitted on 11 May 2012

HAL is a multi-disciplinary open access archive for the deposit and dissemination of scientific research documents, whether they are published or not. The documents may come from teaching and research institutions in France or abroad, or from public or private research centers.
L'archive ouverte pluridisciplinaire HAL, est destinée au dépôt et à la diffusion de documents scientifiques de niveau recherche, publiés ou non, émanant des établissements d'enseignement et de recherche français ou étrangers, des laboratoires publics ou privés. 


\section{Chemical migration in drinking water stored in polyethylene terephthalate}

\section{(PET) bottles: a source of controversy.}

Cristina Bach ${ }^{\mathrm{a}, \mathrm{b}^{*}}$, Xavier Dauchy ${ }^{\mathrm{a}}$, Marie-Christine Chagnon ${ }^{\mathrm{c}}$, and Serge Etienne ${ }^{\mathrm{b}}$

\section{Affiliations:}

${ }^{a}$ Anses, Nancy Laboratory for Hydrology, Water Chemistry Department, 40 rue Lionnois, 54000 Nancy, France.

${ }^{\mathrm{b}}$ Institute Jean Lamour, UMR 7198, Department SI2M, Ecole des Mines de Nancy, Nancy University, Parc de Saurupt, CS 14234, 54042 Nancy, France.

'Derttech « Packtox », Université de Bourgogne, 1 Esplanade Erasme - AgroSupdijon Nord, 21000 Dijon, France.

"Corresponding author: Cristina BACH; email: Cristina.BACH@anses.fr;

Tel: +33 3833887 29; Fax: + 33383388720 


\section{Abstract:}

Due to its chemical inertness and physical properties PET is particularly suitable for food packaging applications, especially for drinking water. More bottled water is consumed than other bottled beverages. This article is a survey and toxicological investigation of chemical compounds, which are able to diffuse from PET bottles to water. The exact detailed chemical composition of plastic materials is known only from information provided by manufacturers. A declaration of conformity according to EC regulation no.10/2011 is required to ensure the safety of plastic materials in contact with foodstuffs. This regulation established a positive list of monomers and additives which are authorized for use in plastic materials. Some substances are subject to restrictions and/or specifications according to their toxicological data. However, Non-Intentionally Added Substances (NIAS) not listed in this regulation such as breakdown products from monomers and additives and/or impurities found in initial polymerization reactants may be present in a PET bottle wall. Also, recycled PET can be a source of unknown chemical compounds found in water. All these substances may potentially migrate from the PET bottle wall to bottled water.

It is well-known that acetaldehyde and antimony are leached from PET bottles. However, several studies have shown the presence of other substances not expected a priori in bottled water, sometimes in non-negligible concentrations. The origin of these compounds has not been clearly established and remains controversial (PET container, cap sealing resins, background contamination, water processing steps, NIAS, etc). Overall, it is difficult to compare the reported results due to the variety of parameters favoring the release of substances (contact time, type of simulant, temperature, sunlight exposure and bottle color). Considering all these difficulties and controversies, further investigations are needed to clearly identify the migration products from PET and to ensure that the consumption of PETbottled water does not involve any health hazards. 


\section{Keywords:}

Bottled water, migration, acetaldehyde, mutagenicity, genotoxicity, endocrine disruptors.

\section{$\underline{\text { List of abbreviations: }}$}

Ag: Silver

Al: Aluminum

APEOs: Polyethoxylated nonylphenols

As: Arsenic

Ba: Barium

BBP: Benzylbutyl phthalate

BHET: Bis(hydroxyethyl) terephthalate

BHT: Butylated hydroxytoluene

BPA: Bisphenol A

Ce: Cesium

Cd: Cadmium

Co: Cobalt

Cr: Chromium

$\mathrm{Cu}$ : Copper

DBP: Dibutyl phthalate

DiBP: Di-iso-butyl phthalate

DEHP, Di-2-(ethylhexyl) phthalate

DEHA: Bis-2-ethylhexyl adipate

DEP: Diethyl phthalate

DMSO: Dimethyl sulfoxide

DOP: Di-n-octyl phthalate

EEC: European Economic Community

EEQs: Estradiol equivalents

Fe: Iron

GC-MS: Gas chromatography - Mass spectrometry

Ge: Germanium

HDPE: High density polyethylene

HULYs: Human blood lymphocytes

LDH: Lactate dehydrogenase 
Mg: Magnesium

Mn: Manganese

Mo: Molybdenum

MTT: 3-(4,5-dimethylthiazol-2-yl)-2,5-diphenyl tetrazolium bromide

NIAS: Non-intentionally added substances

Ni: Nickel

NP: 4-Nonylphenol

OP: Octylphenol

PA: Polyamide

$\mathrm{Pb}$ : Lead

PC: Polycarbonate

PET: Polyethylene terephthalate

PhA: Phthalic acid

PVC: Polyvinylchloride

$\mathrm{Sb}$ : Antimony

$\mathrm{Sb}_{2} \mathrm{O}_{3}$ : Antimony trioxide

Se: Selenium

SEC-HPLC: Size exclusion chromatography - High performance liquid chromatography

SML: Specific migration limits

SPE: Solid-phase extraction

SPME: Solid-phase micro-extraction

SODIS: Solar water disinfection

RPE: Relative proliferative effects

TDI: Tolerable daily intake

TNPP: Tris(nonylphenyl) phosphite

TOC: Total Organic Carbon

Ti: Titanium

YES: Yeast estrogen screen

Zn: Zinc

Zr: Zirconium 


\section{Contents}

1. Introduction.

1.1 Polyethylene terephthalate (PET) used for drinking water bottles.

1.1.1 The synthesis of PET.

1.1.2 The manufacture of PET bottles for drinking water.

1.2 European regulations for plastic food contact materials.

2. Substances investigated in PET-bottled drinking water.

2.1 PET monomers and oligomers.

2.2 Traces of metals.

2.2.1 Antimony.

2.2.2 Other metals.

2.3 Carbonyl compounds.

2.3.1 Carbonyl compounds in PET raw material, preforms and bottles.

2.3.2 Studies of migration of carbonyl compounds into PET-bottled water.

\subsection{Plasticizers.}

2.4.1 Phthalates.

2.4.2 Bis-2-ethylhexyl adipate (DEHA).

2.5 Antioxidants.

2.5.1 Alkylphenols.

2.5.2 Butylated hydroxytoluene (BHT).

2.6 UV stabilisers.

2.7 Lubricants.

2.8 Bisphenol A.

3. Toxicological evaluation of PET-bottled water.

3.1 Cytotoxicity assays.

3.2 Genotoxicity assays.

3.3 Endocrine disruptor assays.

4. Discussion and conclusions.

5. References. 


\section{Introduction.}

The consumption of bottled water is very widespread. For example, more than $53000 \mathrm{~m}^{3}$ were drunk in Europe in 2004, which was the biggest annual consumption thus far (Gleick et al., 2006). Polyethylene terephthalate (PET) is a semi-crystalline polymer belonging to the family of polyesters. It is the most widespread polymer used for the manufacture of food contact packaging and films, especially for beverages and drinking water. PET bottles for drinking water have been marketed for the last four decades and were introduced to the French market at the beginning of the 1980's. PET bottles have gradually replaced polyvinyl chloride (PVC) and glass bottles in markets. The use of this material has enabled the manufacture of light, unbreakable and highly transparent containers (ILSI, 2000).

During this time, numerous studies have investigated the interaction of PET bottles in contact with drinking water. These studies focused on the release of PET initial reactants (monomers and catalysts), reaction by-products and plastic additives into bottled water. The monitoring of several substances by migration-controlled processes that simulate actual storage conditions with respect to time, temperature, and sunlight exposure has also been widely reported (Franz et al., 2004; Widén et al., 2004; Feigenbaum et al., 2005; Vitrac et al., 2007; Welle and Franz, 2008; Franz and Welle, 2009a).

Furthermore, the potential toxicity of bottled water packed in PET has also been investigated. Several authors have reported finding chemical mixtures with estrogenic activity in PETbottled water. The presence of NIAS has been suggested as the source of this toxicological effect (Evandri et al., 2000; Leivadara et al., 2008). Although compounds used for the manufacture of plastic packaging are carefully controlled, the stressing of material during their production can change the chemical structures and generate degradation products, which may have an estrogenic activity (Yang et al., 2011). 
A review of the literature shows that contradictory results for PET-bottled water have been reported concerning the presence of chemical compounds and hazard assessments. These differences could be explained by the large variety of analytical methods, bioassays and exposure conditions involved. Furthermore, in some cases, the origin of substances found in bottled drinking water was not clearly established and remains to be elucidated. For the moment, the safety of PET bottles for drinking water is still in question.

\subsection{Polyethylene terephthalate (PET) used for drinking water bottles.}

\subsubsection{The synthesis of PET.}

The prepolymerization of dimethylterephthalate or terephthalic acid with ethylene glycol is the first industrial step in the synthesis of PET. Both reactions generate low weight oligomers and an intermediate compound named bis(hydroxyethyl)terephthalate (BHET). After this step, a second polycondensation is carried out with an antimony $(\mathrm{Sb})$, germanium $(\mathrm{Ge})$, titanium (Ti), cobalt (Co), magnesium (Mg) or zinc (Zn) based catalyst (ILSI, 2000; Fakirov, 2002).

During PET manufacturing, several degradation and decomposition reactions can be produced (Zimmerman, 1977; McNeill and Bounekhel, 1991; Montaudo et al., 1993). Romão et al., (2009b) reviewed the degradation mechanisms and secondary reactions on PET synthesis. Temperature and oxygen in the PET melt process can promote thermo-mechanical and thermo-oxidative reactions. Sub-products such as acetaldehyde, oligomers and diethylene glycol may be generated and they are potential migrants presents in PET raw material (Besnoin and Choi, 1989).

Hydrolysis is a degradation reaction of PET which can occur due to the presence of water during the melt process (Zhang and Ward, 1995; Paci and La Mantia, 1998). Every chain scission produces carboxyl and alcohol end groups (Campanelli et al., 1993). 
PET thermal degradation generates volatile organic compounds. Carbon monoxide, aldehydes (formaldehyde, acetaldehyde, benzaldehyde), $\mathrm{C}_{1}-\mathrm{C}_{4}$ aliphatic hydrocarbons, aromatic hydrocarbons (benzene, toluene, ethylbenzene and styrene), esters (vinyl benzene, methyl acetate), methanol, acetophenone and 2-methyl-1,3-dioxolane were identified in PET samples submitted to temperatures between 200 and $300^{\circ} \mathrm{C}$ (Dzięcioł and Trzeszczyński, 2000). Franz and Welle (2008) reported 1,3-dioxolane and 2-methyl-1,3-dioxolane as thermal degradation products in PET bottles.

However, Holland and Hay (2002b) have shown that PET thermal stability depends on the type of co-monomers used for its production. Concerning bottle-grade PET, a copolymerization with diethylene glycol and isophthalic acid is usually done to minimize polymer thermal crystallization during production of preforms and the blow-molding process. Both co-monomers reduce the size of spherulites and as a result, the final container is transparent (Holland and Hay, 2002a). Indeed, glass-like transparency is a valued commodity for drinking-water bottles. Also, the crystallization rate has a direct effect on the barrier properties of PET. Gas permeability and the diffusion rate are directly affected by the degree of crystallinity and the orientation of PET films and bottles (Awaja and Pavel, 2005; Tadmor and Gogos, 2006; Romão et al., 2009a).

\subsubsection{The manufacture of PET bottles for drinking water.}

In the packaging industry, bottles and containers can be produced by different techniques. Injection blow molding is the preferred process for manufacturing PET bottles. Amorphous preforms are obtained by processing PET granules. Preforms are stretched by a blow molding process to achieve biaxially oriented bottles (ILSI, 2000; Pennarun, 2001; Awaja and Pavel, 2005).

The barrier properties of PET bottles are the combined result of higher deformation-induced crystallization ( $25 \%$ for carbonated beverage bottles) and orientation. The selection of an 
adequate blow temperature around $20^{\circ} \mathrm{C}$ above the PET glass transition temperature $(\mathrm{Tg})$ is essential to achieve these properties (Tadmor and Gogos, 2006).

Additives such as plasticizers and antioxidants are not necessary for PET bottles and colorants are added in small quantities. Copper phthalocyanine blue is used as a pigment for food contact packaging. Benzotriazole UV stabilizers are added in PET to protect some kinds of food from light. For example, Tinuvin 326 is added into bottle grade PET to protect edible oil against photo-oxidation. Also, acetaldehyde scavengers are used in PET bottles for mineral water (Ashby, 1988; ILSI, 2000; Coltro et al. 2003; FSA, 2007). Villain et al., (1995) have tested various stabilizers to minimize the generation of acetaldehyde and formaldehyde by thermal degradation of PET during the injection molding of preforms. A method for the manufacturing of PET bottles with acetaldehyde scavengers was designed and patented by Jen (2002). Furthermore, it is generally known that antioxidants with hindered phenol containing calcium and a phosphorus stabilizer are used to product PET resins. Hexanedioic acid polymer with 1,3-benzenedimethanamine is another acetaldehyde scavenger used in PET bottles made of a sheet of polyamide (PA) between two PET layers (multi-layer structure). The addition of this scavenger inhibits the yellowing of the polymer caused by the chemical reaction of PA with acetaldehyde. However, the interaction of PET with this scavenger could produce degradation products such as hexanedioic acid and 1,3-benzenedimethamine monomers, oligomers and breakdown products similar to the degradation of PA (FSA, 2007). The PA layers can also generate NIASs as shown by Franz and Welle (2008).

Nowadays, the recycling of PET bottles is a common environmentally-friendly procedure, used to reduce plastic waste and to reprocess the material for other applications. It is assumed that plastic packaging waste could contain residual contaminants from previous use (storage of detergents, pesticides, fuel...etc.) and that these substances may represent a health risk (Demertzis et al. 1997, Awaja and Pavel, 2007). Decontamination of PET is an important step 
for eliminating the presence of unknown compounds in the polymeric material. In Europe, EC Regulation no. 282/2008 has set guidelines for the recycling of plastics for food contact applications. A variety of recycling technologies has been developed for plastic packaging. Awaja and Pavel (2005) have reviewed the PET recycling process for industrial applications.

\subsection{European regulations for plastic food contact materials.}

The characteristics of plastic materials intended to come into contact with food are governed by the Framework European Regulation no.1935/2004 (EU, 2004). This regulation covers17 groups of different materials. It states that food contact material should not transfer its constituents to food in quantities that could incur a human health risk, cause an unacceptable change in the composition of the food or bring about deterioration in the organoleptic characteristics of the food. Regulation no.1935/2004 is complemented with specific measures depending on the type of material. Food contact plastic materials are covered by the recent regulation no 10/2011 (EU, 2011) published in January in the Official Journal of the European Community and which repeals directives 2002/72/EC, 80/766/EEC and 81/432/EEC. This new regulation applies to materials and articles made solely of plastic and it has been extended to include plastic layers in multi-material, multi-layers products. It establishes authorized monomers and additives in the plastic formulation on a positive list. The conformity of a plastic material to come in contact with food is based on migration tests. The overall migration limit should not exceed $10 \mathrm{mg}$ of the total constituents released for $\mathrm{dm}^{2}$ of packaging surface. A specific migration limit (SML), established according to the toxicological data is provided for some substances on the positive list. The principal limitation of this regulation concerns impurities and breakdown products generated by authorized initial reactants and additives (NIASs). Furthermore, the new regulation specifies: "the notion of the risk due to the substance concerns the substance itself, the impurities of this substance and any reaction or degradation products". 
The main aim of this article is to provide a compilation of all known and still controversial data about substances which have been found in PET-bottled drinking water. The experimental migration conditions, the toxicological approaches and the source of water pollution will be discussed in order to clarify the relevance of PET packaging as a source of the migration of chemical compounds into bottled drinking water.

\section{Substances investigated in PET and PET-bottled water.}

\subsection{PET monomers and oligomers.}

Several authors have reported residual reactants and low molecular weight breakdown products in PET bottles as potential migrants. Concerning the presence of monomers and residual reactants in the polymer, Begley et al. (2004) quantified terephthalic acid (6.9 mg/L), monohydroxy ethylene terephthalic acid $(34.4 \mathrm{mg} / \mathrm{L})$, BHET $(49.1 \mathrm{mg} / \mathrm{L})$ and cyclic trimer (9592 mg/L) in commercial beverage PET bottles. Ethylene glycol and terephthalic acid were also identified by Kim et al. (1990) in amber PET bottles for pharmaceutical uses.

Several authors have identified oligomers in PET bottles used for mineral water and foods (Barnes et al., 1995; Monteiro et al., 1998; Nasser et al., 2005). In PET bottles graded for mineral water, Mutsuga et al. (2005) reported levels of oligomers ranging from 4.9 to 8.7 $\mathrm{mg} / \mathrm{g}$.

There is a lack of studies of monomer migration from PET to bottled water. Morelli-Cardoso et al. (1997) carried out ethylene glycol migration experiments in 16 virgin PET bottles coming directly from the Brazil packaging industry. The bottles were filled with distilled water, $3 \%$ of aqueous acetic acid and $15 \%$ of aqueous ethanol. For all cases, ethylene glycol migration was detected after 10 days at $40^{\circ} \mathrm{C}$. In contrast, Monarca et al. (1994) detected terephthalic acid and dimethyl terephthalate in distilled water contained in PET bottles stored under the same conditions. 
A review of the literature did not turn up any other studies of diffusion into PET-bottled water. Food simulants such as aqueous acetic acid, aqueous ethanol or those found directly in fatty foods, for example olive oil, are usually used to study the overall migration of these compounds (Kashtock and Breder, 1980; Ashby, 1988; Castle et al., 1989). Commission Regulation no 10/2011 specified SMLs for ethylene glycol and BHET of $30 \mathrm{mg} / \mathrm{kg}$ and 60 $\mathrm{mg} / \mathrm{kg}$, respectively.

\subsection{Traces of metals.}

Inorganic species may be present as residues from the catalysts or additives used to produce PET. It is known that $\mathrm{Sb}_{2} \mathrm{O}_{3}$ is the most important catalyst used in the synthesis of PET (EU, 2008). Concentrations of antimony (Sb) were found in the range of 168 to $216 \mathrm{mg} / \mathrm{kg}$ in four brands of PET bottles (Nishioka et al., 2002). Westerhoff et al. (2008) detected $213 \mathrm{mg} / \mathrm{kg}$ of $\mathrm{Sb}$ in one PET bottle brand after microwave digestion and Keresztes et al. (2009) found between 210 and $290 \mathrm{mg} \mathrm{Sb} / \mathrm{kg}$ in 10 different brands.

Ti and Ge based catalysts are also known to be used. Westerhoff et al. (2008) have analyzed 23 metals in PET bottles. The highest concentrations were found for $\mathrm{Co}, \mathrm{Cr}, \mathrm{Fe}$, and $\mathrm{Mn}$, with $27 \mathrm{mg} / \mathrm{kg}, 0.11 \mathrm{mg} / \mathrm{kg}, 1.3 \mathrm{mg} / \mathrm{kg}$, and $0.34 \mathrm{mg} / \mathrm{kg}$, respectively. The relatively low levels of these concentrations observed in the polymeric material as compared to $\mathrm{Sb}$, explain why so few studies have been made of the migration of these trace metals into bottled drinking water.

The following subsections present studies of the migration of these inorganic species from PET to bottled water. The results are discussed separately for antimony and the other trace metals taken together. The results of all reviewed studies of Sb migration into PET-bottled water are shown in Table 1.

\subsubsection{Antimony.}


Ashby (1988) has investigated the effect of various parameters (food simulant, exposure temperature, and exposure time) on the migration of $\mathrm{Sb}$. Even at a high temperature $\left(230^{\circ} \mathrm{C}\right.$ for $2 \mathrm{~h}$ ), Sb has low levels of migration (less than $10 \mu \mathrm{g} / \mathrm{L}$ ). Shotyk et al. (2006) found unambiguous evidence of Sb leaching from PET containers by studying 63 brands of bottled water coming from Canada and Europe. Comparisons with analyses of the pristine groundwater and the same water available in glass bottles, in which there is no antimony, have confirmed that water is polluted by PET containers. The median Sb concentration in the European bottled waters was $0.343 \mu \mathrm{g} / \mathrm{L}$, the maximum value being less than $0.8 \mu \mathrm{g} / \mathrm{L}$. In another publication, Shotyk and Krachler (2007), authors found an Sb concentration of $2 \mu \mathrm{g} / \mathrm{L}$ or more in two brands of PET-bottled water. They also studied the effect of storage time. After a period of 6 months at room temperature, $\mathrm{Sb}$ concentrations were found to have increased by $90 \%$ on average in 48 brands of bottled drinking water from European countries. In contrast, using 9 commercial brands of bottled water purchased in Arizona, Westerhoff et al. (2008) did not find any statistical differences with samples stored at $22^{\circ} \mathrm{C}$ after 3 months. On the other hand, they did establish that high temperature storage had a significant effect on the release of Sb. Those results were confirmed by Keresztes et al. (2009) and Cheng et al. (2010). In contrast, both authors concluded that sunlight irradiation has a lower effect on $\mathrm{Sb}$ leaching than temperature.

Concerning the influence of bottle color, Westerhoff et al. (2008) observed that the release of $\mathrm{Sb}$ into ultrapure water was 4 times greater with clear PET bottles than with blue-colored ones. In their study, equal dimensions of the two PET samples (clear and blue) were incubated in $1 \mathrm{~L}$ of ultrapure water at $60^{\circ} \mathrm{C}$ for 10 days. In contrast, Reimann et al. (2010) observed that $\mathrm{Sb}$ leaching increases with dark colored bottles as compared to clear bottles. Surprisingly, Sb was also detected by Reimann et al. (2010) in water in dark green glass bottles but in smaller concentrations than in PET. The main reason for its appearance in glass bottled water is that 
$\mathrm{Sb}_{2} \mathrm{O}_{3}$ is usually used in small quantities as a refining agent in glass manufacturing to remove gas bubbles and to obtain more homogeneous glass (Doremus, 1994).

Ten different Hungarian brands of PET-bottled still mineral water and sparkling mineral water were investigated by Keresztes et al. (2009). Authors have demonstrated that $\mathrm{Sb}$ leaching increases rapidly during the first storage period and then the Sb diffusion reaches a "steady state". They have also noticed that the rate of Sb dissolution into water was higher into sparkling water than into still water, due to the lower $\mathrm{pH}$ of the carbonated water. The higher release of $\mathrm{Sb}$ due to the $\mathrm{pH}(\mathrm{pH}=4.0)$ was also observed by Cheng et al. (2010), who also detected the lowest Sb concentrations in ultrapure water contained in washed PET bottles. The authors concluded that the $\mathrm{Sb}$ in the bottled water came not only from the PET material but that the water had also been partially contaminated during the bottling process.

Keresztes et al. (2009) have shown, as was expected, that the Sb level in bottled water depends on the contact surface area. Higher concentrations were found in smaller bottles. Sometimes, the migration experiments were carried out by placing plastic test samples in an appropriate container with a known volume of food simulant. Migration levels were not directly obtained by analyzing the Sb concentration in the water of a capped bottle, but by using the ratio between the sample surface area and the volume of eluted solution (Nishioka et al., 2002).

\subsubsection{Other metals.}

Few results have been reported from the leaching of other trace metals into PET-bottled water. Ashby (1988) investigated the Co migration from PET bottles stored for 10 days at $40^{\circ} \mathrm{C}$. The Co concentration in water was below the method's detection limit $(<3 \mu \mathrm{g} / \mathrm{L})$. Recently, Cheng et al. (2010) assayed the release of 15 inorganic elements (Al, V, Cr, Mn, $\mathrm{Co}, \mathrm{Ni}, \mathrm{Cu}, \mathrm{As}, \mathrm{Se}, \mathrm{Mo}, \mathrm{Ag}, \mathrm{Cd}, \mathrm{Ba}, \mathrm{Tl}, \mathrm{Pb})$ in 5 different brands of commercial bottles 
subjected to different conditions (low $\mathrm{pH}$, outdoor sunlight irradiation, in-car storage, cooling, heating and microwave treatment). No significant traces of these metals in water were found by the authors. Reimann et al. (2010) found more metals leaching from glass $(\mathrm{Ce}, \mathrm{Pb}, \mathrm{Al}$ and $\mathrm{Zr}$ ) than from PET bottles.

To summarize this section on metal traces in PET-bottled water, all of the studies agreed that $\mathrm{Sb}$ is the most relevant element leaching from PET bottles. The main reason is that antimony trioxide $\left(\mathrm{Sb}_{2} \mathrm{O}_{3}\right)$ is widely employed as a catalyst in the synthesis of PET (Welle and Franz, 2011). Only a small fraction of the Sb contained in PET is released into the water (Nishioka et al., 2002). Welle and Franz (2011) have simulated migration as a function of the amounts of $\mathrm{Sb}$ in PET bottle wall (224 and $350 \mathrm{mg} / \mathrm{L}$ ) and with different water volumes (500 to 1500 $\mathrm{mL}$ ). With identical contact conditions it was shown that higher bottle volumes released lower levels of Sb. According to the authors, the Sb diffusion in the worst case of exposure never reached the SML laid down in the European packaging regulation. Data given in Table 1 never exceeded the SML of $0.04 \mathrm{mg} / \mathrm{kg}$ prescribed for this compound in the European legislation (EU, 2011).

A review of the literature shows that the $\mathrm{Sb}$ diffusion increases with temperature, storage time and low $\mathrm{pH}$. Also, all authors agree that the migration appears to be less significant as a function of sunlight exposure of PET containers than of the other factors. However, there were contradictory conclusions concerning the effect of bottle color on Sb migration. Whereas Westerhoff et al. (2008) detected an increase in the Sb concentration in clear PET bottles as compared to colored ones, Reimann et al. (2010) concluded the opposite.

\subsection{Carbonyl compounds.}

Several carbonyl compounds have been reported to be present in bottled drinking water and in PET packaging. Volatile organic compounds are generated in PET by thermal degradation. . 
Acetaldehyde is generated during the polymerization reaction and the melt process during manufacturing of PET bottles. The scission of the polymer chain bonds leads to the formation of carboxyl and vinyl ester chain ends. Acetaldehyde is formed by the combination of these two end groups as a reaction sub-product (Lorusso et al. 1985; Romão et al., 2009b). Formaldehyde is formed by an internal cleavage of the polymeric chain (Kovarskaya et al., 1968).

\subsubsection{Carbonyl compounds in PET raw material, preforms and bottles.}

When investigating amounts of carbonyl compounds in PET containers, Dong et al. (1980) detected acetaldehyde levels between $0.5 \mu \mathrm{g} / \mathrm{g}$ and $6 \mu \mathrm{g} / \mathrm{g}$ in PET bottle-grade resins. Popoff and Pujolle (1988) reported average acetaldehyde levels in pellets of between 3.12 and 2.6 $\mu \mathrm{g} / \mathrm{g}$ and in preforms of $0.75 \mu \mathrm{g} / \mathrm{g}$ by means of an inter-laboratory test. These authors identifies some parameters that could influence the level of acetaldehyde in PET bottles, namely, the humidity of pellets, the injection time and temperature required to produce performs. They also pointed out the importance of controlling temperature during the injection of preforms, since if the temperature rises by a few degrees then preforms with an acetaldehyde concentration higher than $10 \mu \mathrm{g} / \mathrm{g}$ can be generated. Furthermore, Villain et al. (1994) and Choodum et al. (2007) confirmed that the amounts of acetaldehyde and also formaldehyde in industrial PET were highly dependent on the molecular weight of the polymer and bottle-blowing temperature.

Eberhartinger et al. (1990) found that acetaldehyde levels in PET bottles ranged between 1.31 $\mu \mathrm{g} / \mathrm{g}$ and $5.65 \mu \mathrm{g} / \mathrm{g}$ which is slightly higher than the results of Linssen et al. (1995). The latter authors detected acetaldehyde levels ranging from $1.7 \mu \mathrm{g} / \mathrm{g}$ to $3.8 \mu \mathrm{g} / \mathrm{g}$ in mineral water in PET bottles. Also, Mutsuga et al. (2005) found acetaldehyde levels in PET bottles from Japan, Europe and North America in ranges of $8.4-25.7 \mu \mathrm{g} / \mathrm{g}, 5.0$ - $13.1 \mu \mathrm{g} / \mathrm{g}$ and $9.1-18.7 \mu \mathrm{g} / \mathrm{g}$, 
respectively. Traces of formaldehyde were also found, ranging between $0.8-3.0 \mu \mathrm{g} / \mathrm{g},<0.5$ $\mu \mathrm{g} / \mathrm{g}-1.6 \mu \mathrm{g} / \mathrm{g}$ and $<0.5 \mu \mathrm{g} / \mathrm{g}-1.2 \mu \mathrm{g} / \mathrm{g}$ in the same Japanese, European and North American containers, respectively. The highest levels of formaldehyde and acetaldehyde in Japanese bottles were attributed to the difference in formulations and in packaging production. In contrast, bottle color does not appear to affect the levels of these two compounds.

To our knowledge, other carbonyl compounds traces have not been found in bottle-grade PET.

\subsubsection{Studies of migration of carbonyl compounds into PET-bottled water.}

The studies of diffusion of carbonyl compounds from the wall of PET bottles to water aimed to determine significant factors (contact time, temperature storage, light exposure, physicochemical properties of drinking water, etc.) that can promote their migration from polymer into bottled water.

A review of the scientific literature showed that the migration of acetaldehyde into bottled water has been widely investigated. However, only a few publications have been devoted to studying the presence of other carbonyl compounds (formaldehyde, propanal, butanal, etc.) in bottled water.

The occurrence of the migration of all carbonyl compounds into PET-bottled drinking water will be reviewed as a function of the significant factors affecting migration, as tested by authors. The results of these studies are given in Table 2.

\section{Influence of contact time, temperature, $\mathrm{pH}$ and $\mathrm{CO}_{2}$ of bottled water.}

The first migration studies focused on acetaldehyde to try and explain undesirable taste and odor in bottled water. Pepin et al. (1983) examined the relationship between the detection thresholds of this compound in carbonated mineral water and the initial concentrations in the 
PET bottle wall after maximum exposure of 3 months at 25,37 and $45^{\circ} \mathrm{C}$. The use of three grades of PET containers, with acetaldehyde concentrations of $3.0 \mathrm{mg} / \mathrm{L}, 6.8 \mathrm{mg} / \mathrm{L}$ and 8.8 $\mathrm{mg} / \mathrm{L}$, proved that the migration was related to the amount of acetaldehyde in the bottle wall and that it was directly dependent on temperature and time of storage.

Porretta and Minuti (1995) found trace amounts of acetaldehyde in 34 different brands of drinking water purchased from retail outlets. All of the samples of 16 brands of still water exhibited levels of acetaldehyde above the taste threshold of $15 \mu \mathrm{g} / \mathrm{L}$ after 9 months of storage at $42^{\circ} \mathrm{C}$. In contrast, Nijssen et al. (1996) found that acetaldehyde levels in still mineral water in PET bottles were lower than the method detection limit (LOD $=0.5 \mu \mathrm{g} / \mathrm{L}$ ) after 12 weeks of storage at $30^{\circ} \mathrm{C}$. Their stability experiments were carried out at room temperature with the addition of acetaldehyde in still mineral water, boiled still mineral water, still mineral water adjusted to $\mathrm{pH}=3.7$ and carbonated mineral water stored in PET and glass bottles. In all cases, the results showed a decrease of acetaldehyde level in still water over time. The authors suggested that oxygen or traces of metal ions in still mineral water could promote the degradation of acetaldehyde. They indicated acetic acid, acetic anhydride, peracetic acid and trimer paraldehyde as possible products resulting from the oxidation or/and the reduction of acetaldehyde. The stability of formaldehyde and acetaldehyde was also investigated by Mutsuga et al. (2006) in sterilized and unsterilized mineral water. The authors observed that these two compounds disappeared in commercial mineral water stored at $40^{\circ} \mathrm{C}$ over time and explained this as being due to heterotrophic bacteria, which are able to decompose these compounds.

Lorusso et al. (1985) confirmed that a certain level of $\mathrm{CO}_{2}$ promoted the release of acetaldehyde from PET to water. After six months of storage, levels of acetaldehyde in carbonated water increased to $100 \mu \mathrm{g} / \mathrm{L}$ in samples kept at room temperature and at $40^{\circ} \mathrm{C}$, whereas acetaldehyde was not detected in distilled water under the same experimental 
conditions and with the same kind of bottles. Nevertheless, the authors claimed that the levels found in water did not constitute a health hazard according to the Tolerance Daily Intake (TDI) of $6 \mathrm{mg} / \mathrm{L}$ (calculated for a person weighing $60 \mathrm{~kg}$ ) established by the EEC Scientific Committee for Human Feeding in 1983. In contrast, the values found to exceed the organoleptic detection limits for acetaldehyde in water ranged between 4 and $65 \mu \mathrm{g} / \mathrm{L}$ according to the authors.

Only Nawrocki et al. (2002) found nonanal, glyoxal and methylglyoxal and particularly, acetone in different series of samples of bottled water available in Poland directly from a local market. As previously reported by Nijssen et al. (1996), they have also shown, particularly with acetaldehyde, that lower $\mathrm{pH}$ associated with $\mathrm{CO}_{2}$ significantly increased the amounts of these compounds in water. Whereas, after long-term storage (8 to 9 months) they found a decrease in acetaldehyde concentration levels. According to Nawrocki et al. (2002) this phenomenon was linked to the gradual loss of dissolved $\mathrm{CO}_{2}$ as the bottles are not sufficiently tight for the gas. The carbonyls compounds diffuse through the bottle wall similarly to $\mathrm{CO}_{2}$. The influence of carbon dioxide content in bottled water was also studied by Dabrowska et al. (2003). After several experiments, the authors concluded that the $\mathrm{CO}_{2}$ itself was not responsible for the higher amounts of acetaldehyde in bottled water. Actually, it was assumed that the pressure exerted by the gas on the PET wall promoted the diffusion. Another experiment carried out with pieces of PET in contact with de-ionised water at $\mathrm{pH} 4.5$ and 6.5 also revealed that low $\mathrm{pH}$ did not enhance the migration.

Using another approach, Ewender et al. (2003) studied the short and long-term diffusion of acetaldehyde into carbonated and non-carbonated mineral water in 11 refillable and nonrefillable PET bottles. They noticed that the carbonation of water directly influences the diffusion and the stability of acetaldehyde in mineral water as shown by Lorusso et al. (1985), Porretta and Minuti (1995) and Nawrocki et al. (2002). 
In complete contrast to the other publications, Ceretti et al. (2010) did not detect any acetaldehyde in 6 commercial brands of still and carbonated mineral water in PET bottles. Samples were stored at $40^{\circ} \mathrm{C}$ for 10 days according to the standard migration protocol recommended by European Economic Council Directives No.82/711/EEC and No. 93/8/EEC.

\section{Influence of the manufacturing technology and bottling process.}

Levels of formaldehyde, acetaldehyde, propanal and butanal in commercial mineral water coming from different countries were determined by Sugaya et al. (2001). However, the fact that these 4 aldehydes could not be detected in some samples ( 3 samples from France and 2 Japanese products) suggested that the presence of these compounds in mineral water depends on the quality of the PET container and the bottling process. Certainly, the chemical quality of PET bottles depends on the raw material and on the technology used for manufacturing the packaging, Pinto and Reali (2009).

Later on, another research group Dabrowska et al. (2003) thoroughly investigated aldehyde contamination in mineral water in an attempt to explain the origin of these compounds and the parameters affecting diffusion. A production line of carbonated mineral water was monitored. Each step in production of the bottled water from raw water to the finished product was evaluated. The appearance of formaldehyde, acetaldehyde, propanal, nonanal and glyoxal was observed in ozonated water used to disinfect the bottles. This step appeared to be a source of pollution for the PET material and it could be responsible for some carbonyl compounds pollution of mineral water. But the total aldehyde level $(3.2 \mu \mathrm{g} / \mathrm{L}$ in the finished product) was very close to the analysis background. In contrast and in comparison with glass bottles, higher levels of formaldehyde and acetaldehyde were found in water originated from PET bottles after 170 days of storage. These phenomena confirmed that the PET container generates these two compounds. 
Polypropylene caps were also tested by Dabrowska et al. (2003). Pieces of them were stored in de-ionized water at $20^{\circ} \mathrm{C}$ and $60^{\circ} \mathrm{C}$ for several hours. Formaldehyde, acetaldehyde and acetone were detected in the de-ionized water and their levels increased over time and with a rise in temperature. The authors concluded that polypropylene caps were a source of carbonyl compound contamination, and particularly acetone, in bottled water, but with less effect than PET packaging.

Up to now, only these authors have detected acetone in water in PET bottles and they have indicated that acetaldehyde and acetone are equally important carbonyl compounds migrating to bottled water, whereas the source of glyoxal, methylglyoxal and nonanal has not yet been clearly established. Their presence was rather attributed to the origins of the samples and the different kinds of manufacturing processes.

\section{Influence of exposure to sunlight.}

Wegelin et al. (2001), in order to test the efficiency of Solar Water Disinfection (SODIS) studied the formation of photoproducts and their migration in water in PET bottles exposed to sunlight. They observed an increase in the concentration of formaldehyde in the bottled water over the exposure time up to an irradiation rate of $313 \mathrm{kWh} / \mathrm{m}^{2}$. Surprisingly, samples subjected to the maximum irradiation rate $\left(548 \mathrm{kWh} / \mathrm{m}^{2}\right)$ had the same level of formaldehyde as unexposed ones. In contrast, Nawrocki et al. (2002) observed an increase of formaldehyde, acetaldehyde and acetone in carbonated water stored in PET bottles exposed over time to sunlight and ambient temperature.

Using another approach, Strube et al. (2009) investigated UV-light degradation products of fatty acid amides as a source of plastic off-odors in packed mineral water. They identified 14 carbonyl compounds including hexanal, octanal, nonanal and decanal after exposure to natural sunlight. 
After reviewing the literature on the presence of carbonyl compounds, the following conclusions can be drawn:

- The main source of formaldehyde and acetaldehyde in bottled drinking water is PET packaging. Their concentrations in the PET bottle wall depend on the formulations of raw material and on the manufacturing technology used (production of granules, preforms and bottles).

- Most authors agreed that the diffusion of formaldehyde and acetaldehyde was affected by temperature, storage time and carbonation of water associated with the lower $\mathrm{pH}$ in bottled drinking water. However, opposite conclusions about the increase or decrease of the amounts of these two compounds following exposure to sunlight have been drawn by Wegelin et al. (2001) and Nawrocki et al. (2002).

- In some diffusion studies, different authors observed a disappearance of acetaldehyde and also, formaldehyde in commercial still mineral water. The degradation of these compounds by oxygen, traces of metal ions or heterotrophic bacteria present in still water were the main reasons given by these authors to explain the phenomena.

- Other carbonyl compounds have been detected in PET-bottled drinking water, namely: propanal, butanal, nonanal, glyoxal, methylglyoxal and acetone. However, the different steps in the bottling and bottle capping processes could be the source of these compounds in drinking water.

Nevertheless, the LMS (EU, 2011) values established for formaldehyde and acetaldehyde of $15 \mathrm{mg} / \mathrm{kg}$ and $6 \mathrm{mg} / \mathrm{kg}$, respectively, were never observed in the studies of PET-bottled water reviewed (Table 2).

\subsection{Plasticizers.}


The addition of plasticizers to plastic resins is widespread, to improve their softness and flexibility, especially in Polyvinyl Chloride (PVC) up to 20-30\% (Mori, 1979). Di-2EthylHexyl Phthalate (DEHP) is the most widespread plasticizer produced and employed (Oehlmann et al., 2008). Di-2-ethylhexyl adipate (DEHA) is also commonly employed in PVC products to replace phthalates $(\mathrm{Cao}, 2010)$. It has been demonstrated that phthalate esters and also their metabolites induce abnormal reproductive development in animals and that they are endocrine disruptor compounds (Heudorf et al., 2007; Howdeshell et al., 2008). According to references cited by several authors (FSA, 2007; Franz and Welle, 2009b; Cao, 2010) plasticizers (like phthalates) are not believed to be used for manufacturing PET bottles. Further, phthalates in food contact materials are subject to strict regulations. However they have been found in PET material and in water in PET bottles. In this section, the amounts of phthalates and DEHA detected in PET-bottled water will be reviewed and discussed. The results of these studies are given in Table 3.

\subsubsection{Phthalates.}

Phthalates have been detected in the atmosphere (Xie et al., 2006), in aquatic environments (Peijnenburg and Struijs, 2006; Oehlmann et al., 2008), and in drinks and food (Cao, 2010). The major problems in analyzing phthalates lie in various sources of possible contamination. One source is the background pollution that may occur during the sample preparation procedure (Tienpont et al., 2005; Fankhauser-Noti and Grob, 2007; Reid et al., 2007). In their study, Higuchi et al. (2004) have shown that Di-n-Octyl Phthalate (DOP) contamination in mineral water was due to the bottling line and not to the PET bottles. Serôdio and Nogueira (2006) were also very cautious regarding the source of Di-Butyl Phthalate (DBP) in mineral water matrices $(0.35 \mu \mathrm{g} / \mathrm{L})$ suggesting that it might come from the PET bottles. Cap-sealing resins for bottled foods have also been pointed out for their role in DEHP contamination (Hirayama et al., 2001). However, in a recent study no traces of 
phthalates (DMP, DBP, BBP, DEHP) were detected in water after incubation at $40^{\circ} \mathrm{C}$ for 10 days (Ceretti et al., 2010; Guart et al., 2011). Further, the presence of phthalates in glassbottled water confirmed that they might come from water treatment facilities, namely: pipes, storage tanks and filtering systems (Montuori et al., 2008; Leivadara et al. 2008).

However, several reports have claimed that migration from PET bottles could be the explanation for phthalates in bottled water. Mori (1979) was one of the first authors to investigate contamination by phthalate esters (DBP, DEHP and diethyl phthalate (DEP) in water kept in 100-mL bottles. Kim et al. (1990) used Soxhlet extraction with absolute ethanol for 48 hours to achieve a maximum level of migration from amber-colored PET bottles and identified phthalates such as DEHP, DBP and DEP at levels of $820 \mu \mathrm{g} / \mathrm{g}$ polymer, $220 \mu \mathrm{g} / \mathrm{g}$ polymer, and $120 \mu \mathrm{g} / \mathrm{g}$ polymer, respectively. The source of these compounds was attributed to the coloring substance. Comparing the results of analyses of bottled water before and after storage, Casajuana and Lacorte (2003) concluded that poor storage conditions (10 weeks outdoors at temperatures of up to $30^{\circ} \mathrm{C}$ ) increased the concentrations of DBP, BBP and DEHP in bottled water. After exposure, the mean concentrations of DBP, BBP and DEHP were $0.046 \mu \mathrm{g} / \mathrm{L}, 0.010 \mu \mathrm{g} / \mathrm{L}$ and $0.134 \mu \mathrm{g} / \mathrm{L}$, respectively.

Montuori et al. (2008) are the only authors who investigated the presence of phtalic acid (PhA) in water in PET bottles apart from DMP, DEP, DiBP, DBP and DEHP. Their results showed that $\mathrm{PhA}$ was the most abundant phthalate found in bottled water with a maximum level of $3.50 \mu \mathrm{g} / \mathrm{L}$. They also found that the concentrations of phthalates in samples bottled in PET were 20 times higher than in those from glass bottles directly analysed after purchase. They found no correlation between physicochemical water properties and phthalates migration. Nevertheless, in still mineral water higher phthalates levels were detected than in sparkling water. However, they offered no explanation for this. In contrast, Cao (2008) did not observe significant differences of phthalate levels between glass bottled water and 
drinking water in PET containers. Furthermore, they found no significant changes between phthalates migration into carbonated and non-carbonated water.

The effect of other parameters on phthalates migration has been studied by Bošnir et al. (2007). The concentrations of phthalate appeared to be influenced by the $\mathrm{pH}$ level of beverages. Phthalate concentrations were between 5 to 40 times higher in soft drinks $(\mathrm{pH}=3)$ than in mineral water $(\mathrm{pH}=5)$. The authors suggested that acidic $\mathrm{pH}$ stimulates diffusion of phthalates.

As regards sunlight exposure experiments, Schmid et al. (2008) detected DEHP (100 - 710 $\mathrm{ng} / \mathrm{L})$ at a level 7 times higher than for the blank samples $(110 \mathrm{ng} / \mathrm{L})$. In this study, the authors concluded that the contribution of plasticizer migration was not significant. Amiridou and Voutsa (2011) have also conducted experiments with PET bottles under outdoor conditions. They detected low traces of DEP (33 ng/L) and DBP (44 ng/L) and higher concentrations of DEHP (350 ng/L) in PET-bottled drinking water.

Several studies have yielded data on the content of phthalates in bottled water immediately after purchase, but without examining the migration parameters (time and storage conditions). The initial levels were frequently lower than $0.4 \mu \mathrm{g} / \mathrm{L}$ (Page and Lacroix, 1995; Peñalver et al., 2000; Kayali et al., 2006; Montuori et al., 2008).

\subsubsection{Di-2-ethylhexyl adipate (DEHA).}

Kim et al. (1990) identified DEHA in amber-colored PET bottles with a maximum amount of $560 \mu \mathrm{g} / \mathrm{g}$ in PET obtained by Soxhlet extraction. The authors reported that this value represented the maximum migration level into food. However, it was assumed that this level would be never reached under actual storage conditions. 
Investigation the occurrence of DEHA in bottled drinking water, Serôdio and Nogueira (2006) found that DEHA concentrations in bottled water $(0.15 \mu \mathrm{g} / \mathrm{L})$ were slightly higher than in tap water $(0.09 \mu \mathrm{g} / \mathrm{L})$. In contrast, DEHA was above the method detection limit of $17 \mathrm{ng} / \mathrm{L}$ in all carbonated and non-carbonated samples analysed by Cao (2008).

The influence of sunlight exposure and temperature related to DEHA levels in PET-bottled water was investigated by Schmid et al. (2008) in a SODIS treatment of water. The differences in DEHA concentrations in bottled water were observed in relation to increased temperatures and samples from different countries (Honduras, Nepal and Switzerland) were compared. The highest DEHA level of $0.044 \mu \mathrm{g} / \mathrm{L}$ at $60^{\circ} \mathrm{C}$ with sunlight exposure was found in PET bottles from Honduras.

Following a review of reported studies in the literature, it should be noted that the phthalate esters and DEHA were found to have a wide range of concentrations in bottled water depending on the study in question. One reason could be the sample extraction methods used. The traditional methods (liquid-liquid extraction) led to high background levels and also a high risk of external contamination, whereas solid phase extraction (SPE) and solid-phase micro-extraction (SPME) generated more accurate data at lower detection limits. The contrasting results in the literature may also be due to numerous other factors, such as the small number of samples studied, the PET bottle grade quality and differences in the storage conditions (contact time, temperature and light). Another possible explanation is the large variation in the use of plasticizers in the packaging industry over time as reported by Balafas et al. (1999). Samples from the same brands of PET directly purchased in the market were analyzed in 1996 and in 1997. Total phthalate concentrations in the polymer decreased from $138 \mu \mathrm{g} / \mathrm{g}$ to $84 \mu \mathrm{g} / \mathrm{g}$ over a period of 12 months. More recently, Guart et al. (2011) did not find any phthalate in PET samples. However the absence of plasticizers in packaging material does not necessarily mean that these compounds will be absent in packaged food (Page and 
Lacroix, 1995). Up to now however, the origin of these compounds has not been clearly established.

To conclude, it is important to notice that phthalate esters and DEHA observed in the reviewed studies did not exceed the LMS of (EU, 2011). This regulation set up an LMS of 0.3 $\mathrm{mg} / \mathrm{kg}, 30 \mathrm{mg} / \mathrm{kg}, 1.5 \mathrm{mg} / \mathrm{kg}$ and $18 \mathrm{mg} / \mathrm{Kg}$ respectively for DBP, BBP, DEHP and DEHA.

\subsection{Antioxidants.}

The oxidation and photo-oxidation of polymeric material can be inhibited or reduced by using this kind of stabilizer. Small amounts of these substances can be added to the polymer before it is processed. The most widespread antioxidants are hindered phenol inhibitors. However, PET bottles intended for water are usually processed without antioxidants. The addition of triphenylphoshite, triphenylphophate or Irganox 1222 has only been used in PET fibers to improve their hydrolytic stability (Zweifel, 2001).

\subsubsection{Alkylphenols.}

In food packaging manufacture, tris(nonylphenyl) phosphite (TNPP) is used as an antioxidant additive to stabilize several polymers such as rubbers, styrene, vinyl polymers and polyolefines. The oxidation of this additive generates 4-nonylphenol (NP) (McNeal et al., 2000). Another source of NP and also octylphenol (OP) comes from the degradation of polyethoxylated nonylphenols (APEOs). APEOs are surfactants that are widely used as cleaning agents in bottle manufacturing; Casajuana and Lacorte (2003). NP is widely found in the environment and known to be an endocrine disrupter (Thiele et al., 1997; Loos et al., 2007; Baugros et al., 2009).

The diffusion studies of NP have focused on PVC and polyethylene (PE) containers (Kawamura et al., 2000; Howe et al., 2001). However, the presence of NP and OP has also 
been investigated in drinking water packaged in PET, although the use of TNPP is not known to be used for the production of PET bottles. Fernandes et al. (2008) determined the NP amounts in a wide variety of food-contact materials. In the case of PET containers, NP was not detected. The authors emphasized that these compounds could be used as antioxidants in the manufacture of laboratory equipment and materials (vessels, tubes, detergents...). Hence, background amounts have to be controlled when analyzing samples.

No differences in NP amounts $(19-78 \mathrm{ng} / \mathrm{L})$ as a function of temperature and time $\left(50^{\circ} \mathrm{C}\right.$ for 8h) were observed by Toyo'oka and Oshige (2000) in 9 types of drinking water bottled in PET. The authors doubt whether PET bottles are a source of alkylphenols. Later on, LoyoRosales et al. (2004) determined levels of NP and OP in spring water bottled in PET, HDPE and PVC. The authors concluded that the source of NP was the water itself or pollution during the container washing steps when the packaging was being manufactured. Although traces of NP and OP were found in the same spring water bottled in PVC and HDPE, neither of the two compounds was observed in the same water bottled in PET. The same authors carried out migration experiments with distilled water according to US FDA test protocols. NP and OP were not observed in water stored in PET at $40^{\circ} \mathrm{C}$ for $240 \mathrm{~h}$. Only PVC and HPDE showed an NP migration from polymer to water that depended directly on temperature and time. The potential migration of NP in PET bottles stored outdoors in comparison to glass bottles was investigated by Casajuana and Lacorte (2003). Water analyses were conducted immediately after samples had been purchased and subsequently exposed for 10 weeks above $30^{\circ} \mathrm{C}$. Although, NP was not detected in any sample after purchase, amounts of these compounds were revealed in 3 samples of 5 tested after the storage. In contrast to these results, water in glass bottles showed NP mean high concentrations of $78 \mathrm{ng} / \mathrm{L}$ and $1730 \mathrm{ng} / \mathrm{L}$ before and after exposure respectively, under the same conditions as the PET bottles, . The authors did not explain the reason for this increase of NP in water in glass bottles, but the 
initial presence of this substance in drinking water stored in glass containers has been attributed to surfactants used for washing glass containers before the water is bottled. Amiridou and Voutsa (2011) have also stored bottles outdoors and directly exposed to sunlight for 15 and 30 days. Low traces of NP (around $10 \mathrm{ng} / \mathrm{L}$ ) and OP (around $2 \mathrm{ng} / \mathrm{L}$ ) were observed. No significant differences in NP and OP amounts before and after exposure were found in the bottled water. In contrast, traces of NP in 21 brands of drinking water bottled in PVC, PE and PET were observed by Li et al. (2010). Concentrations ranged from $108 \mathrm{ng} / \mathrm{L}$ to $298 \mathrm{ng} / \mathrm{L}$ in PET-bottled water. However, the daily intake value of NP calculated for a consumption of $2 \mathrm{~L}$ per day for an adult weighing $60 \mathrm{~kg}$ (USEPA, 2006; USEPA, 2009) did not exceed the tolerable daily intake (TDI) of $5 \mu \mathrm{g} / \mathrm{kg}$ body weight proposed by Nielsen et al. (2000).

More recently, Guart et al. (2011) detected NP and OP only in two of ten samples of PETbottled water tested. The amounts of NP (19 ng/L) et OP (3 ng/L) found agreed with the results of Amiridou and Voutsa (2011). The authors attributed the occurrence of these two compounds to the use of NP and OP in the specific manufacture of polymers depending on the bottle brands.

\subsubsection{Butylated hydroxytoluene (BHT).}

BHT is a phenolic antioxidant used in plastic packaging, rubbers, cosmetics and also as a food additive. It is widely used as a thermostabilizer for polyethylene, polypropylene, polyesters and polyvinyl chloride (Sheftel, 2000; Tombesi and Freije, 2002). BHT is on the positive list of the European regulation with an SML of $3 \mathrm{mg} / \mathrm{kg}$.

Kim et al. (1990) identified BHT and its processing breakdown product (2,6-bis-(1,1)methylethyl)-4-ethyl phenol) in PET commercial amber bottles by means of Soxhlet extraction and gas chromatography/mass spectrometry (GC-MS) methods. However analysis of the PET bottles using another GC/MS methodology and Size Exclusion Chromatography - 
High Performance Liquid Chromatography (SEC-HPLC) did not reveal any trace of this compound (Monteiro et al., 1996; Monteiro et al., 1998).

Concerning the occurrence of BHT in PET-bottled water, Tombesi and Freije (2002) found quantifiable amounts of this compound in 5 of 15 samples of PET-bottled water with concentrations ranging between $21.5-38.0 \mu \mathrm{g} / \mathrm{L}$. Later on, the same research group Tombesi et al. (2004) detected BHT in three samples of bottled water but concentrations were ten times lower than in the first studies. The authors claimed that the amounts measured do not exceed the levels recommended by the European Union standards for total phenols in drinking water. Nevertheless, the origin of this compound in drinking water was not discussed. In contrast, Higuchi et al. (2004) found a concentration of $2.5 \mu \mathrm{g} / \mathrm{L}$ of this compound in mineral water bottled in glass but BHT was not observed in the same water bottled in PET. The authors concluded that BHT occurrence in mineral water could be due to the use of PE caps.

\subsection{UV stabilizers.}

Up till now, Tinuvin P (2-(2H-benzotriazol-2-yl)-p-cresol) and Tinuvin 234 (2-(2Hbenzotriazol-2-yl)-4,6-bis(1-methyl-1-phenylethyl)phenol) are the only UV stabilizers found with direct analysis of PET bottles. Both compounds are light stabilizers and they are generally used in the production of polystyrene, polyamides, polymethacrylate, polyesters, polyvinyl chloride and polypropylene (Sheftel, 2000). The specific migration limits (SML) of Tinuvin 324 and Tinuvin P were fixed at $1.5 \mathrm{mg} / \mathrm{kg}$ and $30 \mathrm{mg} / \mathrm{kg}$, respectively (EU, 2011). According to (FSA, 2007) these UV absorbers could generate benzotriazole by a photolysis and photo-oxidation mechanism.

Monteiro et al. (1996) developed a high performance size exclusion chromatography method for the quantification of Tinuvin P in PET containers used for vegetable oils. Concentrations ranging from 0.0122 to $0.0124 \mathrm{~g}$ per $100 \mathrm{~g}$ of PET were observed. Later on, the same 
researchers Monteiro et al. (1998) found this compound in PET bottle material using GC MS.

Only a few publications have been devoted to the study of the diffusion of Tinuvin P and Tinuvin 234 from the polymer to fatty-food simulants. Their migration into bottled drinking water has not been reported, which appears to be due to the insolubility of these compounds in water. Besides, the diffusion coefficient of Tinuvin 324 experimentally calculated in $95 \%$ ethanol at $40^{\circ} \mathrm{C}$ after 10 days is very low (of the order of $10^{-17} \mathrm{~cm}^{2} / \mathrm{s}$ ) (Monteiro et al., 1999; Begley et al., 2004).

\subsection{Lubricants.}

Lubricants are another kind of additives that are generally used for the production of plastic packaging in order to minimize the adhesion of food, to reduce friction or to promote the elasticity of the material (Schaefer et al., 2003). A later study confirmed that these additives are used in the manufacture of packaging and also for the maintenance of technological equipment (Č́ížková et al., 2009). Fatty acid amides are also a kind of lubricant used for the manufacture of polyolefin closures. Lubricants such as erucamide and also oleamide are authorized in Europe for the manufacture of plastic materials intended to come in contact with food (EU, 2011). No SMLs have been prescribed for these substances.

To our knowledge, erucamide and oleamide are not used in the manufacture of PET bottles. However, erucamide could be used in the manufacture of bottle closures to facilitate their removal from the container on opening (Shi et al., 2004). This could explain why they are found in mineral water in concentrations ranging from $2.0 \mathrm{ng} / \mathrm{L}$ to $182 \mathrm{ng} / \mathrm{L}$ as observed by Buiarelli et al. (1993) and Monteiro et al. 1996. It is important to notice that erucamide could generate oxidation products when exposed to sunlight according to Strube et al. (2009). 


\subsection{Bisphenol A.}

Bisphenol A (BPA) is a moiety used in the manufacture of epoxy resins and polycarbonate plastics (PC) for food packaging (McNeal et al., 2000). It is known to be an endocrine disrupting chemical that may cause harmful effects in animals and probably in humans (Thiele et al., 1997; Berryman et al., 2004). The time and period of exposure to BPA are particularly significant parameters to take into account. Most studies of the release of these substances from food contact materials have focused on PC baby bottles (Biles et al., 1997; Brede et al., 2003; Biedermann-Brem et al., 2008). Few publications have been devoted to the investigation of this compound in PET-bottled water.

Toyo'oka and Oshige (2000) were the first authors to identify BPA in 9 different samples of PET-bottled drinking water purchased in a local market. Concentrations were found to range from $3 \mathrm{ng} / \mathrm{L}$ to $10 \mathrm{ng} / \mathrm{L}$. The authors found that BPA concentrations in water remained constant before and after heating PET bottles at $50^{\circ} \mathrm{C}$ for $8 \mathrm{~h}$, and could not therefore incriminate the PET material as a source of BPA. In contrast, a slight increase of $7 \mathrm{ng} / \mathrm{L}$ in the amount of BPA after 10 weeks exposure up to $30^{\circ} \mathrm{C}$ was observed by Casajuana and Lacorte (2003).

As for studies of the influence of sunlight in the migration of BPA into PET-bottled water, outdoor experiments were conducted for 15 and 30 days by Amiridou and Voutsa (2011). Low concentrations (up to $4 \mathrm{ng} / \mathrm{L}$ ) of BPA were observed in PET-bottled water before and after exposure to sunlight. In contrast, Shao et al. (2005) did not find any BPA in 13 different kinds of beverages, including drinking water, packaged in PET analyzed immediately after purchasing. In contrast, Li et al. (2010) detected traces of BPA in 17 brands of bottled water from China under the same conditions (analyzed immediately after purchase). The concentrations of BPA found in bottled drinking water varied greatly. The concentrations ranged from 17.6 to $324 \mathrm{ng} / \mathrm{L}$. However, the material of which the water container was made 
(PVC, PE or PET) was not specified. Furthermore it was suggested that the water itself may have been polluted prior to bottling. Furthermore, another source of BPA in PET-bottled water could be due to the containers' caps. Recently, BPA was identified in unbuffered HPLC water in contact with HDPE, LDPE and PS bottle caps by Guart et al. (2011) using the standard UNE-EN 13130 method to determine the specific migration of plastic materials, whereas this compound was not found in water in contact with PET cuts. The samples were incubated for 10 days at $40^{\circ} \mathrm{C}$ and the migration levels from the three different caps materials to HPLC water were around $0.1 \mathrm{mg} / \mathrm{dm}^{2}$.

In any case, the presence of BPA was surprising because this compound is not used in the production of PVC, PE, PET and PS. Sax et al. 2010 reported that one possible explanation for some compounds not expected in bottled water could be the use of recycled PET.

\section{Toxicological evaluation of PET-bottled water.}

Only the substances on the positive list established in regulation 10/2011 may be used for the manufacturing of plastic materials intended to come in contact with food. Thus, overall migration experiments must be performed to prove the conformity of plastic material with the regulation. Further, as limits have been fixed for several substances on the basis of their toxicological potential (Severin et al., 2011), specific migration must also be checked. Although, food contact packaging is tightly controlled by European regulations, it has been suggested that food packaging may leach estrogenic substances (Muncke, 2009; Yang et al., 2011); PET has being pointed out in this controversial subject as a possible source (Pinto and Reali, 2009; Sax, 2010; Wagner and Oehlmann, 2010).

\subsection{Cytotoxicity assays.}


A biological and chemical approach to PET bottles and to their intermediate components (resins and preforms) in contact with water was performed by Sauvant et al. (1995). PET resins and preforms were incubated in distilled water for $24 \mathrm{~h}$ and 10 days at room temperature $\left(20-22^{\circ} \mathrm{C}\right)$. The PET bottles were filled with mineral water and the maximum storage time was 24 months at room temperature. Several cytotoxic effects using different endpoints were measured in the murin fibroblasts L-929 cell line, namely: the cellular growth, the lactate dehydrogenase activity $(\mathrm{LDH})$ release, the reduction of the tetrazolium salt 3-(4,5dimethylthiazol-2-yl)-2,5-diphenyl tetrazolium bromide (MTT), the neutral red incorporation or release of the protein content and the RNA synthesis kinetics.

A significant cytotoxicity was observed in the RNA synthesis, MTT reduction and LDH release assays, when the PET resins and preforms were in contact with distilled water for 10 days. In contrast, no cytotoxic effects in mineral water stored in PET bottles for 24 months were observed. In all cases, no mineral elements and acetaldehyde were detected. The authors thus concluded that only the finished product has to be controlled following the manufacture of PET bottles.

\subsection{Genotoxicity assays.}

The mutagenicity of non-volatile and volatile compounds in PET mineral water was investigated using the Ames test, by De Fusco et al. (1990). Two independent experiments were conducted with unconcentrated and concentrated water. On the one hand, the PET mineral water was concentrated with silica bonded-phase cartridges after exposure of half of the samples to daylight and the other half to darkness for 1, 3 and 6 months. On the other hand, the test was performed with unconcentrated distilled water in PET bottles exposed at $40^{\circ} \mathrm{C}$ for 10 days and in daylight for 1 month at room temperature. Concerning the concentrated water extracts, only samples stored for 1 month revealed a mutagenic activity with the Salmonella strain TA 98 and with metabolic activation (+S9). The mutagenic activity 
was twice as high when samples were stored in daylight (mutagenicity ratio of 3.6). These effects were observed only with the concentrated distilled water whatever the storage conditions and the authors suggested that it was due to the use of a concentration factor. In contrast, Monarca et al. (1994) carried out a GC-MS chemical analysis of non-volatile compounds leached into distilled water and contained in green PET bottles. The diffusion experiments to evaluate the total migration were performed according to the conditions specified in the European Council directives $\mathrm{N}^{\circ} 82 / 711 / \mathrm{EEC}$ and $\mathrm{N}^{\circ} 93 / 8 / \mathrm{EEC}\left(40^{\circ} \mathrm{C}\right.$ at 10 days) and in USFDA (1980) $\left(120^{\circ} \mathrm{C}\right.$ for 2 hours). Several compounds were detected in distilled water stored in PET bottles, namely: acetaldehyde, acetic acid, propanal, terephtalic acid, dimethyl terephthalate, phenol-2,6-bis(1,1-dimethylethyl)-4,4-methyl and 1,2benzenedicarboxylic acid butyl-2-methyl-propyl ester. A toxicological assay (Ames test) of carbonated mineral water kept in the same kind of PET bottles was performed. The mineral water was concentrated using silica $\mathrm{C}_{18}$ cartridges after daylight storage $(1,3,6$ months at room temperature). The Ames test results for the concentrated extracts showed no mutagenic activity with Salmonella strains TA 98 and TA 100 (with and without S9) whatever the time periods.

Using plant models, toxicities in commercial mineral waters after daylight and temperature exposures were observed by Evandri et al. (2000) and Biscardi et al. (2003). Evandri et al. (2000) performed three different migration experiments under controlled storage conditions. Two brands of still mineral water packaged either in PET or in glass were tested using the Allium cepa assay. An increase of the Allium cepa chromosomic aberrations was observed in PET water samples exposed to direct sunlight for 16 weeks (twofold induction) and exposed in the dark at $40^{\circ} \mathrm{C}$ for 10 days (threefold induction). These disturbances were attributed to the migration of volatile compounds into PET-bottled water. However, the results may be not representative because very few PET brands were tested. 
Biscardi et al. (2003) compared the presence of chemical compounds in PET-bottled water (still and carbonated) collected directly from the spring source with those filled at a commercial bottling plant. Mutageneticity tests were performed every month in lyophilised mineral water stored in PET bottles during 12 months. On the one hand, the Tradescantia micronucleus bioassay was carried out with the addition of distilled water into lyophilised samples. On the other hand, mineral water powder was reconstituted with organic solvents to perform the Comet assay with human leukocytes. In parallel, analyses of the migrants were carried out using GC-MS. It is important to note that lyophilisation is an unusual technique for concentrating water and that the authors did not describe the pre-treatment protocol used for their samples. DCWRRC (1985) described a procedure using evaporation under a low vacuum to obtain a dried solids powder, and this technique makes it possible to keep only non-volatile compounds. An eightfold increase in the micronuclei frequency compared to distilled water was observed for concentrated still mineral water (50-fold) contained in PET bottles after 2 months in storage. Significant DNA damages in human cells were observed only in PET-bottled water collected in the bottling plant. It was suggested that the distribution pipelines in the bottling plant were a source of mutagens in mineral water. DEHP was identified in the water extracts $(3.2 \mathrm{mg} / \mathrm{L})$ in still and carbonated mineral water after 12 months in storage. As DEHP is not genotoxic (Butterworth et al., 1984; Dybing, 2002), its presence could not explain the toxic effect observed. Ceretti et al. (2010) found that genotoxic effects could be associated with mineral and $\mathrm{CO}_{2}$ content of the water using the Tradescantia micronucleus test and Allium Cepa assay. However, authors concluded that these findings should be regarded with caution because of the small number of samples tested. In contrast, the Human Blood Lymphocytes (HULYs) bioassay was used to evaluate the toxicity of PETbottled drinking water by Ergene et al. (2008). No significant effect was observed on the sister chromatid exchange for natural spring water and purified drinking water stored in PET for 8 
weeks after bottling. Despite this, the same commercial water caused a cytostatic effect on the HULYs culture.

It is important to note that some kinds of water have a lower $\mathrm{pH}$ compared to the extracellular media used in bioassays. Furthermore media need to be buffered to prevent false positive responses in the assay due to a change in the extracellular $\mathrm{pH}$. The $\mathrm{pH}$ and also the conductivity of water must to be checked to ensure that the physico-chemical properties of water itself are not of the cause of the positive response.

\subsection{Endocrine disruptor assays.}

Endocrine disruptors are compounds that mimic or antagonize the actions of natural estrogens, and are the most common form of endocrine disruptor activity (NRC, 1999; ICCVAM, 2003, 2006). These compounds alter the hormone system involved in many biological metabolisms and can produce many health-related problems, such as early puberty in females, reduced sperm counts, altered functions of reproductive organs, obesity, altered gender-specific behaviors, and increased rates of some breast, ovarian, testicular, and prostate cancers (Kabuto et al., 2004; Newbold et al., 2004; Della Seta et al., 2006; Patisaul et al., 2006; Patisaul et al., 2009).

Some authors have reported estrogenic activity in mineral water in PET bottles, using bioassays such as the E-Screen (MCF-7 cell line) and Yeast assays (S. cerevisae) expressing the human estrogen receptor $\alpha(\mathrm{ER} \alpha)$. Estrogenic activity was also evaluated using a reproduction test performed with mudsnails, Potamopyrgus antipodarum (Pinto and Reali, 2009; Wagner and Oehlmann, 2009; Sax, 2010; Wagner and Oehlmann, 2010). All, these studies suggested the presence of endocrine disruptors in PET-bottled water.

Contamination of bottled water by endocrine disruptors could occur at the different steps of the bottling process, namely: untreated groundwater from a spring, supply pipes or the filling 
and cleaning of containers in the bottling process (Montuori et al., 2008; Wagner and Oehlmann, 2009; Sax, 2010). Furthermore, for some authors plastic bottle stress (UV radiation and heat) could also be a source of endocrine disruptors (Yang et al., 2011).

The mineral composition of water itself could be a source of estrogenic activity as suggested by Criado et al. (2005) using fungi growth as a model after 5 incubation months in PETbottled water. Spore suspensions of Alternaria alternate, Penicillium citrinum and Clasdosporium cladosporioides were inoculated into 12 PET bottles of natural mineral water and 12 PET bottles of mineralized water (potable water with added salts). They concluded that salts in mineral water could be at the origin of the growth.

Several compounds have been pointed out as being the source of the hormonal activity. As shown in Section 2.4.1, several authors have detected phthalates in PET-bottled water (Casajuana and Lacorte, 2003; Bošnir et al., 2007; Montuori et al., 2008). Criado et al. (2005) reported that the level of DBP increased by $20 \%$ in bottled water after 5 months of storage. However, no $P$. citrinum growth was detected after the addition of a range of concentrations of DBP in sterilized water. Further, phthalates are not used as additives in the manufacturing of PET bottles (ILSI, 2000). Furthermore contamination cannot be excluded in the studies of Montuori et al. (2008) and Bošnir et al. (2007), as they did not prove the absence of phthalates in mineral and soft drinks before bottling. In any case, even if they had been present individually, the estrogenic activity of these compounds is too weak (Jobling et al., 1995), particularly for DEHP to explain these data.

As reported in Section 2.2.1 Sb was found in PET-bottled water. Sax (2010) mentioned that $\mathrm{Sb}$ could be also a source of estrogenicity. Indeed, Choe et al. (2003) observed a high estrogenicity of antimony chloride using the estrogen receptor dependant, transcriptional expression assay and the E-Screen test. However, the most common catalysts used in PET synthesis are based on antimony oxide, not on chloride (Biros et al., 2002; Duh, 2002; El- 
Toufaili, 2006). Among others (see Section 2.2 and 2.2.1), Takahashi et al.(2008) reported that antimony trioxide $\left(\mathrm{Sb}_{2} \mathrm{O}_{3}\right)$ is initially added in PET synthesis, and that after the polycondensation reaction, $\mathrm{Sb}$ could be found in $\mathrm{PET}$ as $\mathrm{Sb}$ glycolate, either free or bound to the PET polymer chain. In general and in terms of toxicity, it is important to note that the effect of inorganic species depends on their oxidation state with the trivalent form being the more toxic form (Filella et al., 2002). Some works focused on the study of Sb speciation in PET bottles and PET-bottled water. Martin et al. (2010) observed an Sb trivalent form in the matrix of PET bottles using synchrotron X-ray. In contrast, no trivalent Sb was detected in PET-bottled water by Zih-Perényi et al. (2008).

Recently, Yang et al. (2011) reported on the necessity to test the estrogenicity of monomers and additives used in the manufacture of plastics in their original unstressed form and after stressing. The authors claimed that all plastics subjected to "stress" could leach xenoestrogenic substances, even those that have no estrogenic activity at the initial step (formulation). The estrogenic activity of PET water bottles was evaluated by an E-screen assay using MCF-7 cells. The saline extracts of PET showed estrogenic activity (RME response $>15 \%$ ) for all stress conditions (microwave, sunlight, autoclave). However, no chemical analyses were performed in parallel to identify the compounds involved in the observed effect.

For other authors, estrogenicity could be due to the use of recycled PET (Safa, 1999). Sax (2010) suggested that DMP concentration in PET bottled-soda detected by Bošnir et al. (2007) could be due to the use of recycled PET coming from shampoo bottles and intended for bottling of soft drinks. 
Furthermore, the extraction efficiency of estrogen-like compounds from bottled water depends on the water preparation techniques (SPE, evaporation) (Wagner and Oehlmann, 2010).

In each case when biological data were provided, there was insufficient analytical data to enable us to draw a conclusion.

Pinto and Reali (2009) reported low estrogenic activity, but with great variability, in 9 Italian brands of PET-bottled water using a Yeast Estrogen Screen (YES) bioassay. The water samples were concentrated using C18 cartridges and the extracts were dissolved in dimethyl sulfoxide (DMSO). The highest estrogenic activity observed in one brand of mineral water was $23.1 \mathrm{ng} / \mathrm{L}$ EEQ. However, with the other brands of mineral water, hormonal activity was often found to be in the same range as for tap water from groundwater and surface water (15.1 $\mathrm{ng} / \mathrm{L}$ and $17.2 \mathrm{ng} / \mathrm{L}$, respectively).

Another research group, Wagner and Oehlmann (2009) tested 18 brands of commercial PET and glass-bottled water using the yeast estrogen screen (YES) assay. The same water, contained either in PET or in glass, was tested. Compared to glass, a weak increase of the estrogenic activity in PET-bottled water was observed in 3 of 4 brands. The maximum value (75.2 ng/L of EEQ) was obtained with water packaged in a non-reusable PET bottle. A reproduction test with Potamopyrgus antipodarum mudsnails was also performed by (Wagner and Oehlmann, 2009) to detect endocrine disrupters. Mudsnails were inserted in PET bottles that had previously been filled with culturing water. The parthenogenetic generation of embryos was investigated. Although the differences were not statistically significant, the authors claimed that the production of embryos per female increased slightly in PET bottles suggesting that estrogenic contamination comes from PET packaging. However, no correlation was observed with the similar brands between both assays and nothing proved 
whether the effect was really due to PET or to a contamination. Furthermore, the American Chemistry Council (ACC, 2009) reported that PET is not a source of estrogenic compounds. More recently, Wagner and Oehlmann (2010), in a complement to their previous article, investigated the influence of sample preparation techniques to extract estrogenic compounds from bottled water. The effectiveness of solid-phase extraction cartridges and the evaporation treatment of the water extracts were investigated.

The choice of an appropriate cartridge sorbent for solid phase extraction (SPE) has been shown to be a critical step for detecting estrogenic activity in the bottled water extracts, since the traditional C18 silica cartridges entrap more estrogenic compounds. Concerning the water sample treatment, authors observed a significant difference in estrogenic activity between the extracts evaporated with or without addition of dimethyl sulfoxide (DMSO). Extracts with DMSO showed higher relative proliferative effects (RPE) 4-fold more than the extracts evaporated without DMSO. Therefore, the authors pointed out that volatile organic compounds kept in DMSO could be the cause of the higher estrogenic activity. Using the Escreen assay, the optimized preparation (C18 cartridges + evaporation with DMSO), revealed the highest estrogenic activity, which was 3-fold higher in PET-bottled water than in water packaged in glass.

Franz and Welle (2009b) ruled out PET packaging as being responsible for this hormonal activity observed, using theoretical models of migration with potential xenoestrogenic candidates such as nonylphenol and bisphenol A. According to the authors, the endocrine disruptors alone have too low an estrogenic potency to explain this effect. Consequently, a chemical mixture, or "cocktail effect", and/or unknown compounds (NIAS) could be at the source of the estrogenic activity observed, with low concentrations of endocrine disruptors giving rise to a synergistic effect (Muncke, 2009). 
Again, no analytical data were provided in parallel, underlying the need to combine chemical analysis with bioassays to clearly identify these compounds and to understand the potential risk of exposure for humans. Furthermore, it is very important to check the steps involved and to make a rational evaluation of the observed effect by identifying and quantifying the possible entry pathways of these compounds.

\section{Discussion and conclusions}

Food contact packaging is tightly regulated. European regulation No 1935/2004 underlines that: "Any material or article intended to come into contact directly or indirectly with food must be sufficiently inert to preclude substances from being transferred to food in quantities large enough to endanger human health or to bring about an unacceptable change in the composition of the food or deterioration in its organoleptic properties". The LMS values established in regulation $\mathrm{N}^{\circ} 10 / 2011$ are calculated on the basis of toxicological data. Contaminants released from food-contact materials are still a controversial subject, especially concerning estrogenic activity, and PET has also been incriminated as seen in this review. Throughout this paper, it should be noted that authors used different storage conditions to evaluate the migration of compounds from PET into bottled drinking water. Different analytical methods with sensitive detection limits were employed to identify or/and quantify these substances in a large variety of PET bottles. Since migration depends directly on these factors, the comparison of data is difficult, sometimes impossible and often controversial. The same problem is true of the toxicological studies performed on bottled drinking water. Depending on the type of assay (yeast, human cell lines, snails, Allium Cepa, etc.) and sample preparation (lyophilized, concentrated, etc.) different conclusions were drawn. Further, plant systems (Allium Cepa, Tradescandia) are not considered as primary screening tools by current international guidelines for mammalian systems making extrapolation very difficult (Evandri et al., 2000). 
Also, it is important to specify that very few studies combined the chemical water analysis and toxicological evaluation at the same time.

Nowadays, it is well-known and all scientific reports agree, that formaldehyde and acetaldehyde are thermal degradation products of PET and that they could be released into the bottled water depending on certain storage parameters and according to the type of drinking water (Nawrocki et al., 2002; Dabrowska et al., 2003; Mutsuga et al., 2006). It is assumed that $\mathrm{Sb}$, a catalyst residue in PET synthesis, could also migrate into the bottled water (Shotyk and Krachler, 2007; Westerhoff et al., 2008; Keresztes et al., 2009).

Concerning the presence of carbonyl compounds in PET-bottled water, in all studies and for all storage conditions (shown in Table 2), levels of formaldehyde and acetaldehyde, did not exceed the specified migration limits (SML) of $15 \mathrm{mg} / \mathrm{kg}$ and $6 \mathrm{mg} / \mathrm{kg}$, respectively (EU, 2011). Despite this, acetaldehyde exceeds the water organoleptic threshold (between 20-40 $\mu \mathrm{g} / \mathrm{L})$. Furthermore, the odor of water stored in PET bottles compared to that of soft drinks, can be detected at very low levels, due to the absence of masking flavor compounds (Pepin et al., 1983; Nijssen et al., 1996).

Apart from these well-known compounds, which are normally not a problem, we may conclude that it is necessary to be cautious before claiming that there is a direct link between PET use and the compounds found in bottled drinking water. PET is the polymer which uses the least additives (ILSI, 2000). Phthalates, nonylphenol, antioxidants, UV stabilizers, lubricants and carbonyl compounds in PET-bottled water could come from several sources, namely: bottle caps, transport pipelines, disinfection agents, background pollution of analytical methods and the bottling process itself or even environmental pollution. Their presence in glass-bottled water as well, as demonstrated by some authors, is another reason to believe in the possibility of their being other sources than PET. 
Less is known about NIAS presence (byproducts, impurities, etc.) in PET bottles and these substances can also migrate into bottled drinking water (Skjevrak et al., 2005; Grob et al., 2006; Franz and Welle, 2008; Muncke, 2009). However, this phenomenon is true for all food contact materials.

The cyto/genotoxic effects and the endocrine disruption activities observed in vitro by some authors have raised doubts and revealed discrepancies in the debate about the quality and the safety of PET-bottled water.

In terms of estrogenic effect, a "cocktail" effect in bottled drinking water with compounds having low endocrine disrupting properties and/or water mineral content could explain these positive results (Criado et al., 2005; Muncke, 2009).

However, more comparable and reliable information on the chemical mixtures and the effect observed in the PET-bottled drinking water is necessary before concluding that there is a potential human health risk. Bioassays do indicate that there is an overall risk, but the use of these bioassays must be standardized as well as the analysis protocols (CEN-OCDE guidelines, ISO). Further, it is necessary to combine toxicological data and chemical analysis, especially when the responses are positive, and to determine the possible entry pathways and concentration of compounds. 


\section{$5 \quad$ References.}

ACC, 2009. American Chemsitry Council. Phthalates Information Center. Available: http://www.phthalates.americanchelistry.com. [accessed 7 July 2011].

Amiridou, D. and Voutsa, D., 2011. Alkylphenols and phthalates in bottled waters. Journal of Hazardous Materials 185(1), 281-286.

Ashby, R., 1988. Migration from polyethylene terephthalate under all conditions of use. Food Additives and Contaminants 5(Suppl. 1), 485-492.

Awaja, F. and Pavel, D., 2005. Recycling of PET. European Polymer Journal 41(7), $1453-$ 1477.

Balafas, D., Shaw, K.J. and Whitfield, F.B., 1999. Phthalate and adipate esters in Australian packaging materials. Food Chemistry 65(3), 279-287.

Barnes, K.A., Damant, A.P., Startin, J.R. and Castle, L., 1995. Qualitative liquid chromatographic-atmospheric-pressure chemical-ionisation mass spectrometric analysis of polyethylene terephthalate oligomers. Journal of Chromatography A 712(1), 191-199.

Baugros, J.B., Cren-Olivé, C., Giroud, B., Gauvrit, J.Y., Lantéri, P. and Grenier-Loustalot, M.F., 2009. Optimisation of pressurised liquid extraction by experimental design for quantification of pesticides and alkyl phenols in sludge, suspended materials and atmospheric fallout by liquid chromatography-tandem mass spectrometry. Journal of Chromatography A 1216(25), 4941-4949.

Begley, T.H., Biles, J.E., Cunningham, C. and Piringer, O., 2004. Migration of a UV stabilizer from polyethylene terephthalate (PET) into food simulants. Food Additives and Contaminants 21(10), 1007-1014.

Berryman, D., Houde, F., DeBlois, C. and O'Shea, M., 2004. Nonylphenolic compounds in drinking and surface waters downstream of treated textile and pulp and paper effluents: a survey and preliminary assessment of their potential effects on public health and aquatic life. Chemosphere 56(3), 247-255.

Besnoin, J.M. and Choi, K.Y., 1989. Identification and characterization of reaction byproducts in the polymerisation of polyethylene terephthalate. Journal of Macromolecular Science - Reviews in Macromolecular Chemistry and Physics C29(1), 55-81.

Biedermann-Brem, S., Grob, K. and Fjeldal, P., 2008. Release of bisphenol A from polycarbonate baby bottles: Mechanisms of formation and investigation of worst case scenarios. European Food Research and Technology 227(4), 1053-1060.

Biles, J.E., McNeal, T.P. and Begley, T.H., 1997. Determination of Bisphenol a Migrating from Epoxy Can Coatings to Infant Formula Liquid Concentrates. Journal of Agricultural and Food Chemistry 45(12), 4697-4700.

Biros, S.M., Bridgewater, B.M., Villeges-Estrada, A., Tanski, J.M. and Parkin, G., 2002. Antimony ethylene glycolate and catecholate compounds: structural characterization of polyesterification catalysts. Inorganic Chemistry 41, 4051-4057. 
Biscardi, D., Monarca, S., De Fusco, R., Senatore, F., Poli, P., Buschini, A., Rossi, C. and Zani, C., 2003. Evaluation of the migration of mutagens/carcinogens from PET bottles into mineral water by Tradescantia/micronuclei test, Comet assay on leukocytes and GC/MS. Science of the Total Environment 302(1-3), 101-108.

Bošnir, J., Puntarić, D., Galić, A., Škes, I., Dijanić, T., Klarić, M., Grgić, M., Čurković, M. and Šmit, Z., 2007. Migration of phthalates from plastic containers into soft drinks and mineral water. Food Technology and Biotechnology 45(1), 91-95.

Brede, C., Fjeldal, P., Skjevrak, I. and Herikstad, H., 2003. Increased migration levels of bisphenol A from polycarbonate baby bottles after dishwashing, boiling and brushing. Food Additives and Contaminants 20(7), 684-689.

Buiarelli, F., Cartoni, G. and Cocciolo, F., 1993. HPLC and GC-MS detection of compounds released to mineral waters stored in plastic bottles of PET and PVC (in Italian). Annali di Chimica 83(3-4), 93-104.

Butterworth, B.E., Bermudez, E., Smith-Oliver, T., Earle, L., Cattley, R., Martin, J., Popp, J.A., Strom, S., Jirtle, R. and Michalopoulos, G., 1984. Lack of genotoxic activity of di(2ethylhexyl)phthalate (DEHP) in rat and human hepatocytes. Carcinogenesis 5(10), 13291335.

Campanelli, J.R., Kamal, M.R. and G., C.D., 1993. A kinetic study of the hydrolytic degradation of polyethylene terephthalate at high temperature. Journal of Applied Polymer Science 48(3), 443-451.

Cao, X.L., 2008. Determination of phthalates and adipate in bottled water by headspace solidphase microextraction and gas chromatography/mass spectrometry. Journal of Chromatography A 1178(1-2), 231-238.

Cao, X.L., 2010. Phthalate Esters in Foods: Sources, Ocurrence, and Analytical Methods. Comprehensive Reviews in Food Science and Food Safety 9(1), 21-43.

Casajuana, N. and Lacorte, S., 2003. Presence and release of phthalic esters and other endocrine disrupting compounds in drinking water. Chromatographia 57(9-10), 649-655.

Castle, L., Mayo, A., Crews, C. and Gilbert, J., 1989. Migration of poly(ethylene terephthalate)(PET) oligomers from PET plastics into foods during microwave and conventional cooking and into bottled beverages. Journal of Food Protection 52(5), 337-342.

Ceretti, E., Zani, C., Zerbini, I., Guzzella, L., Scaglia, M., Berna, V., Donato, F., Monarca, S. and Feretti, D., 2010. Comparative assessment of genotoxicity of mineral water packed in polyethylene terephthalate (PET) and glass bottles. Water Research 44(5), 1462-1470.

Cheng, X., Shi, H., Adams, C.D. and Ma, Y., 2010. Assessment of metal contaminations leaching out from recycling plastic bottles upon treatments. Environmental Science and Pollution Research 17(7), 1323-1330.

Choe, S.Y., Kim, S.J., Kim, H.G., Lee, J.H., Choi, Y., Lee, H. and Kim, H., 2003. Evaluation of estrogenicity of major heavy metals. The Science of the Total Environment 312(1-3), 1521. 
Choodum, A., Thavarungkul, P. and Kanatharana, P., 2007. Acetaldehyde residue in polyethylene terephthalate (PET) bottles. Journal of Environmental Science and Health - Part B Pesticides, Food Contaminants, and Agricultural Wastes 42(5), 577-583.

Č́́žková, H., Voldřich, M., Ševčík, R. and Pivoňka, J., 2009. Off-flavour defects of packed waters and soft drinks. Czech Journal of Food Sciences 27(SPEC. ISS. 2), S379-S381.

Coltro, L., Padula, M., Saron, E.S., Borghetti, J. and Buratin, A.E.P., 2003. Evaluation of a UV absorber added to PET bottles for edible oil packaging. Packaging Technology and Science 16(1), 15-20.

Criado, M.V., Fernández Pinto, V.E., Badessari, A. and Cabral, D., 2005. Conditions that regulate the growth of moulds inoculated into bottled mineral water. International Journal of Food Microbiology 99(3), 343-349.

Dabrowska, A., Borcz, A. and Nawrocki, J., 2003. Aldehyde contamination of mineral water stored in PET bottles. Food Additives and Contaminants 20(12), 1170-1177.

DCWRRC, 1985. Water Resources Research Center, Report N66: Chemical Separation of Water Samples. University of the District of Columbia. Washigton (USA)

De Fusco, R., Monarca, S., Biscardi, D., Pasquini, R. and Fatigoni, C., 1990. Leaching of mutagens into mineral water from polyethyleneterephthalate bottles. Science of the Total Environment 90, 241-248.

Della Seta, D., Minder, I., Belloni, V., M., A.A., Dessi-Fulgheri, F. and Farabollini, F., 2006. Pubertal exposure to estrogenic chemicals affects behavior in juvenile and adult male rats. Hormonal Behaviour 50, 301-307.

Dong, M., Di Edwardo, A.H. and Zitomer, F., 1980. Determination of residual acetaldehyde in polyethylene terephthalate bottles, preform and resins by automated headspace gas chromatography. Journal of Chromatographic Science 18, 242-246.

Doremus, R.H., 1994. Glass Science, $2^{\text {nd }}$ Edition, John Wiley \& sons, New York (USA).

Duh, B., 2002. Effect of antimony catalyst on solid-state polycondensation of poly(ethylene terephthalate). Polymer 43(11), 3147-3154.

Dybing, E., 2002. Development and implementation of the IPCS conceptual framework for evaluating mode of action of chemical carcinogens. Toxicology 181-182, 121-125.

Dzięcioł, M. and Trzeszczyński, J., 2000. Volatile products of polyethylene terephthalate thermal degradation in nitrogen atmosphere. Journal of Applied Polymer Science 77(9), 18941901.

Eberhartinger, S., Steiner, I., Washüttl, J. and Kroyer, G., 1990. Study of the migration of acetaldehyde from PET bottles into soft drinks containing carbonic acid. Untersuchungen zur Migration von Acetaldehyd aus Polyethylenterephthalat-Flaschen für kohlensäurehaltige Erfrischungsgetränke. Zeitschrift für Lebensmittel-Untersuchungund-Forschung 191(4-5), 286-289.

El-Toufaili, F.A., 2006. Catalytic and mechanistic studies of polyethylene terephthalate synthesis, Université de Berlin, Berlin (Allemagne). 
Ergene, S., Çelik, A., Çavaş, T., Köleli, N. and Aymak, C., 2008. The evaluation of toxicity and mutagenicity of various drinking waters in the human blood lymphocytes (HULYs) in vitro. Food and Chemical Toxicology 46(7), 2472-2475.

EU, 2011. Commission regulation (EU) No 10/2011 of 14 January 2011 on plastic materials and articles intended to come in contact with food, Official Journal of the European Commission.

EU, 1982. Council directive 82/711/EEC of 18 October 1982 laying down the basic rules necessary to testing migration of the constituents of plastic materials and articles intended to come into contact with foodstuff.

EU, 1993. Council Directive 93/8/EEC of 19 December 1985 laying down the list of simulants to be used for testing migration of constituents of plastic materials and articles intended to come into contact with foodstuffs

EU, 2008. European Union Risk Assessment Report Diantimony Trioxide, CAS No: 1309-644, EINECS No: 215-175-0, Office for official publications of the European Communities, Luxembourg.

EU, 2004. Regulation No 1935/2004 of the European Parliament and of the council of 27 october 2004 on materials intended to come into contact with food and repealing directives 80/590/EEC and 89/109/EEC.

Evandri, M.G., Tucci, P. and Bolle, P., 2000. Toxicological evaluation of commercial mineral water bottled in polyethylene terephthalate: A cytogenetic approach with Allium cepa. Food Additives and Contaminants 17(12), 1037-1045.

Ewender, J., Franz, R., Mauer, A. and Welle, F., 2003. Determination of the migration of acetaldehyde from pet bottles into non-carbonated and carbonated mineral water. Deutsche Lebensmittel-Rundschau 99(6), 215-221.

Fakirov, S., 2002. Handbook of thermoplastic polyesters, Vol. 1, Wiley-VCH, Weinheim (Germany).

Fankhauser-Noti, A. and Grob, K., 2007. Blank problems in trace analysis of diethylhexyl and dibutyl phthalate: Investigation of the sources, tips and tricks. Analytica Chimica Acta 582(2), 353-360.

Feigenbaum, A., Dole, P., Aucejo, S., Dainelli, D., De La Cruz Garcia, C., Hankemeier, T., N'gono, Y., Papaspyrides, C.D., Paseiro, P., Pastorelli, S., Pavlidou, S., Pennarun, P.Y., Saillard, P., Vidal, L., Vitrac, O. and Voulzatis, Y., 2005. Functional barriers: Properties and evaluation. Food Additives and Contaminants 22(10), 956-967.

Fernandes, A.R., Rose, M. and Charlton, C., 2008. 4-Nonylphenol (NP) in food-contact materials: Analytical methodology and ocurrence. Food Additives and Contaminants 25(3), 364-372.

Filella, M., Belzile, N. and Yu-Wei, C., 2002. Antimony in the environment: a review focused on natural waters II. Relevant solution chemistry. Earth-Science Reviews 59(1-4), 265-285. 
Franz, R., Mauer, A. and Welle, F., 2004. European survey on post-consumer polyethylene terephthalate (PET) materials to determine contamination levels and maximum consumer exposure from food packages made from recycled PET. Food Additives and Contaminants 21(3), $265-286$.

Franz, R. and Welle, F., 2009a. Can migration of endocrine disruptors from plastic bottles be the cause of estrogenic burden recently determined in bottled mineral water? Deutsche Lebensmittel-Rundschau 105(5), 315-318.

Franz, R. and Welle, F., 2009b. Can migration of endocrine disruptors from plastic bottles be the cause of estrogenic burden recently determined in bottled mineral water?. Deutsche Lebensmittel-Rundschau 105(5), 315-318.

Franz, R. and Welle, F., 2008. Investigation of non-intentionally added substances (NIAS) in PET bottles and closures, Poster presentation at the $4^{\text {th }}$ International Symposium on Food Packaging, 19-21 November, Prague (Czech Republic).

FSA, 2007. Report FD07/01: An investigation into the reaction and breakdown products from starting substances used to produce food contact plastics, Food Standards Agency, London (United Kindom).

Gleick, P., Wolff, G., Cooley, H., Palaniappan, M., Samulon, A., Lee, E., Morrison, J. and Katz, D., 2006. The World's Water 2006-2007. The Biennal Report on Freshwater Resources., Pacific Institut for Studies in Development, Environment, and Security. Island Press, Oackland, CA.

Grob, K., Biedermann, M., Scherbaum, G., Roth, M. and Rieger, K., 2006. Food contamintion with organic materials in perspective: Packaging materials as the largest and least controlled source? A view focusing on the European situation. Critical Reviews in Food Science and Nutrition 46(7), 529-536.

Guart, A., Bono-Blay, F., Borrell, A. and Lacorte, S., 2011. Migration of plasticizers phthalates, bisphenol A and alkylphenols from plastic containers and evaluation of risk. Food Additives \& Contaminants 28(5), 1-10.

Heudorf, U., Mersch-Sundermann, V. and Angerer, J., 2007. Phthalates: Toxicology and exposure. International Journal of Hygiene and Environmental Health 210(5), 623-634.

Higuchi, A., Yoon, B.O., Kaneko, T., Hara, M., Maekawa, M. and Nohmi, T., 2004. Separation of endocrine disruptors from aqueous solutions by pervaporation: Dioctylphthalate and butylated hydroxytoluene in mineral water. Journal of Applied Polymer Science 94(4), 1737-1742.

Hirayama, K., Tanaka, H., Kawana, K., Tani, T. and Nakazawa, H., 2001. Analysis of plasticizers in cap-sealing resins for bottled foods. Food Additives and Contaminants 18(4), 357-362.

Holland, B.J. and Hay, J.N., 2002a. Analysis of comonomer content and cyclic oligomers of poly(ethylene terephthalate). Polymer 43(6), 1797-1804.

Holland, B.J. and Hay, J.N., 2002b. The thermal degradation of PET and analogous polyesters measured by thermal analysis-Fourier transform infrared spectroscopy. Polymer 43(6), 1835 1847. 
Howdeshell, K.L., Rider, C.V., Wilson, V.S. and Gray Jr, L.E., 2008. Mechanisms of action of phthalate esters, individually and in combination, to induce abnormal reproductive development in male laboratory rats. Environmental Research 108(2), 168-176.

Howe, S.R., Surana, P., Jakupca, M.R. and Borodinsky, L., 2001. Potential dietary exposure to p-nonylphenol from food-contact use of tris(nonylphenyl)phosphite (TNPP). Food Additives and Contaminants 18(11), 1021-1039.

ICCVAM, 2006. Addentum to ICCVAM, Evaluation of In vitro Test Methods for Detection Potential Endocrine Disruptors: Estrogen Receptor and Androgen Receptor Binding and Transcriptional Activation Assays. September, 2006. NIH Pub 03-4503. Available: http://iccvam.niehs.nih.gov/docs/endo_docs/EDAddendFinal.pdf [accessed 7 July 2011].

ICCVAM, 2003. ICCVAM, Evaluation of In vitro Test Methods for Detection Potential Endocrine Disruptors: estrogen Receptor and Androgen Receptor Binding and Transcriptional Activation Assays. May, 2003. NIH Pub 03-4503. Available: http://iccvam.niehs.nih.gov/docs/endo_docs/edfinalrpt0503/edfinrpt.pdf [accessed 7 July 2011].

ILSI, 2000. Packaging materials: 1. polyethylene terephthalate (PET) for food packaging applications, International Life Science Institute, Brussels (Belgium).

Jen, Z.C., 2002. Manufacturing method of copolyester for low acetaldehyde content of PET bottles. Available: http://www.patentstorm.us/patents/6489434-description.html [assessed 7 July 2011].

Jobling, S., Sheahan, D., Osborne, J.A., Mathiessen, P. and Sumpter, J.P., 1995. A variety of environmentally persistent chemicals, including some phthalates plasticizers, are weakly estrogenic. Environmental Health Perspectives 103(6), 582-587.

Kabuto, H., Amakawa, M. and Shishibori, T., 2004. Exposure to bisphenol A during embryonic/fetal life and infancy increases oxidative injury under development of the brain and testis in mice. Journal of Life Science 74(24), 2931-2940.

Kashtock, M. and Breder, C.V., 1980. Migration of Ethylene Glycol from polyethylene terephthalate Bottles into 3\% Acetic Acid. Association of Official Analytical Chemists. 63(2), 168-172.

Kawamura, Y., Maehara, T., Iijima, H. and Yamada, T., 2000. Nonylphenol in food contact plastics and toys. Journal of the Food Hygienic Society of Japan 41(3), 212-218.

Kayali, N., Tamayo, F.G. and Polo-Díez, L.M., 2006. Determination of diethylhexyl phtalate in water by solid phase microextraction coupled to high performance liquid chromatography. Talanta 69(5), 1095-1099.

Keresztes, S., Tatár, E., Mihucz, V.G., Virág, I., Majdik, C. and Záray, G., 2009. Leaching of antimony from polyethylene terephthalate (PET) bottles into mineral water. Science of the Total Environment 407(16), 4731-4735.

Kim, H., Gilbert, S.G. and Johnson, J.B., 1990. Determination of potential migrants from commercial amber polyethylene terephthalate bottle wall. Pharmaceutical research 7(2), 176179. 
Kovarskaya, B.M., Levantovska, I.I., Blyumenfel'd, A.B. and Dralyuk, G.V., 1968. Thermooxidative degradation of polyethylene terephthalate (in Russian). Plasticheskie Massy $5,42-46$.

Leivadara, S.V., Nikolaou, A.D. and Lekkas, T.D., 2008. Determination of organic compounds in bottled waters. Food Chemistry 108(1), 277-286.

Li, X., Ying, G.-G., Su, H.-C., Yang, X.-B. and Wang, L., 2010. Simultaneous determination and assessment of 4-nonylphenol, bisphenol A and triclosan in tap water, bottled water and baby bottles. Environment International 36(6), 557-562.

Linssen, J., Reitsma, H. and Cozijnsen, J., 1995. Static headspace gas chromatography of acetaldehyde in aqueous foods and polythene terephthalate. Zeitschrift für LebensmittelUntersuchung und -Forschung 201(3), 253-255.

Loos, R., Hanke, G., Umlauf, G. and Eisenreich, S.J., 2007. LC-MS-MS analysis and occurrence of octyl- and nonylphenol, their ethoxylates and their carboxylates in Belgian and Italian textile industry, waste water treatment plant effluents and surface waters. Chemosphere 66(4), 690-699.

Lorusso, S., Gramiccioni, L. and Di Marzio, S., 1985. Acetaldehyde migration from poly(ethyleneterephthalate) (PET) containers. GC determination and toxicological assessment. Annali di Chimica 75(9-10), 403-414.

Loyo-Rosales, J.E., Rosales-Rivera, G.C., Lynch, A.M., Rice, C.P. and Torrents, A., 2004. Migration of Nonylphenol from Plastic Containers to Water and a Milk Surrogate. Journal of Agricultural and Food Chemistry 52(7), 2016-2020.

Martin, R.R., Shotyk, W.S., Naftel, S.J., Ablett, J.M. and Northup, P., 2010. Speciation of antimony in polethylene terephthalate bottles. X-Ray Spectrometry 39(4), 257-259.

McNeal, T.P., Biles, J.E., Begley, T.H., Craun, J.C., Hopper, M.L. and Sack, C.A., 2000. Determination of suspected endocrine disruptors in foods and food packaging. ACS Symposium Series 747, 33-52.

McNeill, I.C. and Bounekhel, M., 1991. Thermal degradation studies of terephthalate polyesters: 1. Poly(alkylene terephthalates). Polymer Degradation and Stability 34(1-3), 187204.

Monarca, S., De Fusco, R., Biscardi, D., De Feo, V., Pasquini, R., Fatigoni, C., Moretti, M. and Zanardini, A., 1994. Studies of migration of potentially genotoxic compounds into water stored in pet bottles. Food and Chemical Toxicology 32(9), 783-788.

Montaudo, G., Puglisi, C. and Samperi, F., 1993. Primary thermal degradation mechanisms of PET and PBT. Polymer Degradation and Stability 42(1), 13-28.

Monteiro, M., Nerín, C. and Reyes, F.G.R., 1996. Determination of UV stabilizers in PET bottles by high performance-size exclusion chromatography. Food Additives and Contaminants 13(5), 575-586.

Monteiro, M., Nerín, C. and Reyes, F.G.R., 1999. Migration of Tinuvin P, a UV stabilizer, from PET bottles into fatty-food simulants. Packaging Technology and Science 12(5), 241248. 
Monteiro, M., Nerín, C., Rubio, C. and Reyes, F.G.R., 1998. A GC/MS method for determining UV stabilizers in polyethyleneterephthalate bottles. HRC Journal of High Resolution Chromatography 21(5), 317-320.

Montuori, P., Jover, E., Morgantini, M., Bayona, J.M. and Triassi, M., 2008. Assessing human exposure to phthalic acid and phthalate esters from mineral water stored in polyethylene terephthalate and glass bottles. Food Additives and Contaminants - Part A Chemistry, Analysis, Control, Exposure and Risk Assessment 25(4), 511-518.

Morelli-Cardoso, M.H.W., Tabak, D., Cardoso, J.N., Pereira, A.S. and Abrantes, S., 1997. Application of capillary gas chromatography to the determination of ethylene glycol migration from PET bottles in Brazil. Journal of High Resolution Chromatography 20(3), 183-185.

Mori, S., 1979. Contamination of water and organic solvents stored in plastic bottles with phthalate ester plasticizers. Analytica Chimica Acta 108(1), 325-332.

Muncke, J., 2009. Exposure to endocrine disrupting compounds via the food chain: Is packaging a relevant source? Science of the Total Environment 407(16), 4549-4559.

Mutsuga, M., Kawamura, Y., Sugita-Konishi, Y., Hara-Kudo, Y., Takatori, K. and Tanamoto, K., 2006. Migration of formaldehyde and acetaldehyde into mineral water in polyethylene terephthalate (PET) bottles. Food Additives and Contaminants 23(2), 212-218.

Mutsuga, M., Tojima, T., Kawamura, Y. and Tanamoto, K., 2005. Survey of formaldehyde, acetaldehyde and oligomers in polyethylene terephthalate food-packaging materials. Food Additives and Contaminants 22(8), 783-789.

Nasser, A.L.M., Lopes, L.M.X., Eberlin, M.N. and Monteiro, M., 2005. Identification of oligomers in polyethyleneterephthalate bottles for mineral water and fruit juice: Development and validation of a high-performance liquid chromatographic method for the determination of first series cyclic trimer. Journal of Chromatography A 1097(1-2), 130-137.

Nawrocki, J., Dabrowska, A. and Borcz, A., 2002. Investigation of carbonyl compounds in bottled waters from Poland. Water Research 36(19), 4893-4901.

Newbold, R.R., Jefferson, W.N., Padilla-Banks, E. and Haseman, J., 2004. Developmental exposure to diethylstilbestrol (DES) alters uterine response to estrogens in prepubescent mice: low versus high dose effects. Reproductive Toxicology 18(3), 399-406.

Nielsen, E., Ostergaard, G., Thorup, I., Ladeforged, O., Jelhnes, O. and Jelnes, J.E., 2000. Toxicological evaluation and limit values for nonylphenol, nonylphenol ethoxylates, tricresyl, phosphates and benzoic acid. The Institute of Food Safety and Toxicology. Danish Veterinary and Food Administration Environmental Project Copenhagen: Danish Environmental Protection Agency.

Nijssen, B., Kamperman, T. and Jetten, J., 1996. Acetaldehyde in mineral water stored in polyethylene terephthalate (PET) bottles: Odour threshold and quantification. Packaging Technology and Science 9(4), 175-185.

Nishioka, K., Hirahara, A. and Iwamoto, E., 2002. Determination of antimony in polyethylene terephthalate bottles by graphite furnace atomic absorption spectrometry using microwave sample preparation Bulletin of the Institute of Life Science, Hiroshima Prefectural Women's University 8, 35-42. 
NRC, 1999. National Research Council. Hormonally active agents in the environment. Washington, D. C.: National Academies Press.

Oehlmann, J., Oetken, M. and Schulte-Oehlmann, U., 2008. A critical evaluation of the environmental risk assessment for plasticizers in the freshwater environment in Europe, with special emphasis on bisphenol A and endocrine disruption. Environmental Research 108(2), 140-149.

Paci, M. and La Mantia, F.P., 1998. Competition between degradation and chain extension during processing of reclaimed poly(ethylene terephthalate). Polymer Degradation and Stability 61(3), 417-420.

Page, B.D. and Lacroix, G.M., 1995. The occurrence of phthalate ester and di-2-ethylhexyl adipate plasticizers in Canadian packaging and food sampled in 1985-1989: A survey. Food Additives and Contaminants 12(1), 129 - 151.

Patisaul, H.B., Fortino, A.E. and Polston, E.K., 2006. Neonatal genistein or bisphenol-A exposure alters sexual differentiation of the AVPV. Neurotoxicology and Teratology 28(1), 111-118.

Patisaul, H.B., Todd, K.L., A., M.J. and Adewale, H.B., 2009. Impact of neonatal exposure to the ER $\alpha$ agonist PPT, bisphenol-A or phytoestrogens on hypothalamic kisspeptin fiber density in male and female rats. Neurotoxicology 30(3), 350-357.

Peijnenburg, W.J.G.M. and Struijs, J., 2006. Occurrence of phthalate esters in the environment of the Netherlands. Ecotoxicology and Environmental Safety 63(2), 204-215.

Peñalver, A., Pocurull, E., Borrull, F. and Marcé, R.M., 2000. Determination of phthalate esters in water samples by solid-phase microextraction and gas chromatography with mass spectrometric detection. Journal of Chromatography A 872(1-2), 191-201.

Pennarun, P.Y., 2001. Migration from recycled PET bottles. Elaboration and validation of a model usable of functionnal barriers (in French), University of Reims Champagne-Ardenne, Reims (France).

Pepin, D., Communal, P.Y. and Dupire, B., 1983. Study of mineral water conditionning in terephtalate polyethylene (in French). Journal Français d'Hydrologie 14(1), 105-112.

Pinto, B. and Reali, D., 2009. Screening of estrogen-like activity of mineral water stored in PET bottles. International Journal of Hygiene and Environmental Health 212(2), 228-232.

Popoff, G. and Pujolle, J.P., 1988. A standard method to test terephtalate polyethelene used in drinking water package (in French). Journal Français d'Hydrologie 19(1), 73-81.

Porretta, S. and Minuti, E., 1995. Acetaldehyde in pet-packaged commercial mineral waters and soft drinks: Determination of its content and evaluation of its taste threshold. Industria Conserve 76, 266-274.

Reid, A.M., Brougham, C.A., Fogarty, A.M. and Roche, J.J., 2007. An investigation into possible sources of phthalate contamination in the environmental analytical laboratory. International Journal of Environmental Analytical Chemistry 87(2), 125 - 133. 
Reimann, C., Birke, M. and Filzmoser, P., 2010. Bottled drinking water: Water contamination from bottle materials (glass, hard PET, soft PET), the influence of colour and acidification. Applied Geochemistry 25(7), 1030-1046.

Romão, W., Franco, M.F., Corilo, Y.E., Eberlin, M.N., Spinacé, M.A.S. and De Paoli, M.A., 2009a. Poly (ethylene terephthalate) thermo-mechanical and thermo-oxidative degradation mechanisms. Polymer Degradation and Stability 94, 1849-1859.

Romão, W., Spinacé, M.A.S. and De Paoli, M.A., 2009b. Poly(ethylene terephthalate), PET: A review on the synthesis processes, degradation mechanisms and its recycling (in Portuguese). Polímeros: Ciência e Tecnologia 19(2), 121-132.

Safa, H.L., 1999. Sorption-desorption of aromas on multi-use PET bottles. A test procedure. Packaging Technology and Science 12(1), 37-44.

Sauvant, M.P., Pepin, D. and Bohatier, J., 1995. Chemical and in vitro toxicological evaluations of water packaged in polyvinyl chloride and polyethylene terephthalate bottles. Food Additives and Contaminants 12(4), 567-584.

Sax, L., 2010. polyethylene terephthalate May yield endocrine disruptors. Environmental Health Perspectives 118(4), 445-448.

Schaefer, A., Küchler, T., Simat, T.J. and Steinhart, H., 2003. Migration of lubricants from food packagings: Screening for lipid classes and quantitative estimation using normal-phase liquid chromatographic separation with evaporative light scattering detection. Journal of Chromatography A 1017(1-2), 107-116.

Schmid, P., Kohler, M., Meierhofer, R., Luzi, S. and Wegelin, M., 2008. Does the reuse of PET bottles during solar water disinfection pose a health risk due to the migration of plasticisers and other chemicals into the water? Water Research 42(20), 5054-5060.

Serôdio, P. and Nogueira, J.M.F., 2006. Considerations on ultra-trace analysis of phthalates in drinking water. Water Research 40(13), 2572-2582.

Severin, I., Riquet, A.-M. and Chagnon, M.-C., 2011. Risk assessment and management Food Contact Materials (in French). Cahiers de Nutrition et de Diététique 46(2), 59-66.

Shao, B., Han, H., Hu, J., Zhao, J., Wu, G., Xue, Y., Ma, Y. and Zhang, S., 2005.

Determination of alkylphenol and bisphenol A in beverages using liquid chromatography/electrospray ionization tandem mass spectrometry. Analytica Chimica Acta 530(2), 245-252.

Sheftel, V.O., 2000. Indirect Food Additives and Polymers: Migration and Toxicology, American Chemical Society, Lewis publishers, Boca Raton (USA).

Shi, Y., Liu, H.H. and Rule, M., 2004. Packaged potable liquid with UV absorber for reduced off-taste from closure and method, U. S. Pat. Appl. Publ. CODEN USXXCO U.S. 2004185196 A1 20040923 CAN 141:276665 AN 2004:780156 CAPLUS.

Shotyk, W. and Krachler, M., 2007. Contamination of bottled waters with antimony leaching from polyethylene terephthalate (PET) increases upon storage. Environmental Science and Technology 41(5), 1560-1563. 
Shotyk, W., Krachler, M. and Chen, B., 2006. Contamination of Canadian and European bottled waters with antimony from PET containers. Journal of Environmental Monitoring $8(2), 288-292$.

Skjevrak, I., Brede, C., Steffensen, I.L., Mikalsen, A., Alexander, J., Fjeldal, P. and Herikstad, H., 2005. Non-targeted multi-component analytical surveillance of plastic food contact materials: Identification of substances not included in EU positive lists and their risk assesment. Food Additives \& Contaminants: Part A: Chemistry, Analysis, Control, Exposure \& Risk Assessment 22(10), 1012-1022.

Strube, A., Buettner, A. and Groetzinger, C., 2009. Characterization and identification of a plastic-like off-odor in mineral water. Water Science and Technology: Water Supply 9, 299309.

Sugaya, N., Nakagawa, T., Sakurai, K., Morita, M. and Onodera, S., 2001. Analysis of aldehydes in water by head space-GC/MS. Journal of Health Science 47(1), 21-27.

Tadmor, Z. and Gogos, C.G., 2006. Principles of polymer processing, $2^{\text {nd }}$ Edition, Wiley Interscience, Hohoken, New Yersey, (USA).

Takahashi, Y., Sakuma, K., Itai, T., Zheng, G. and Mitsunobu, S., 2008. Speciation of antimony in PET bottles produced in Japan and China by X-ray absorption fine structure spectroscopy. Environmental science \& technology. 2008(42), 9045-9050.

Thiele, B., Günther, K. and Schwuger, M.J., 1997. Alkylphenol ethoxylates: Trace analysis and environmental behavior. Chemical Reviews 97(8), 3247-3272.

Thompson, D., Parry, S.J. and Benzing, R., 1997. The validation of a method for determining the migration of trace elements from food packaging materials into food. Journal of Radioanalytical and Nuclear Chemistry 217(1), 147-150.

Tienpont, B., David, F., Dewulf, E. and Sandra, P., 2005. Pitfalls and Solutions for the Trace Determination of Phthalates in Water Samples. Chromatographia 61(7), 365-370.

Tombesi, N.B. and Freije, H., 2002. Application of solid-phase microextraction combined with gas chromatography-mass spectrometry to the determination of butylated hydroxytoluene in bottled drinking water. Journal of Chromatography A 963(1-2), 179-183.

Tombesi, N.B., Freije, R.H. and Augusto, F., 2004. Factorial experimental design optimization of solid phase microextraction (SPME) conditions for analysis of butylated hydroxytoluene (BHT) in bottled water. Journal of the Brazilian Chemical Society 15(5), 658663.

Toyo'oka, T. and Oshige, Y., 2000. Determination of alkylphenols in mineral water contained in PET bottles by liquid chromatography with coulometric detection. Analytical Sciences 16(10), 1071-1076.

UNE-EN13130, 2005. Materials and articles in contact with foodstuffs-plastics substances sbject to limitation. Part 1: Guide to test methods for the specific migration of substances from plastics to foods and food simulants and the determination of substances in plastics and the selection of conditions of exposure to food simulants.

UNE-EN-ISO177, 1988. Plastics. Determination of migration of plasticizers. 
USEPA, 2009. Drinking Water Contaminants. U.S. Environmental Protection Agency, EPA 815/R019/011.

USEPA, 2006. Drinking water standards and health advisories. Washington, DC: Office of Water; EPA/822/R-06/013.

USFDA, 1980. Code of Federal Regulations Title 21. Foods and Drugs: Parts 170-199, US Food and Drug Administration Standards.

Villain, F., Coudane, J. and Vert, M., 1994. Thermal degradation of polyethylene terephthalate and the estimation of volatile degradation products. Polymer Degradation and Stability 43(3), 431-440.

Villain, F., Coudane, J. and Vert, M., 1995. Thermal degradation of polyethylene terephthalate: study of polymer stabilization. Polymer Degradation and Stability 49(3), 393397.

Vitrac, O., Challe, B., Leblanc, J.C. and Feigenbaum, A., 2007. Contamination of packaged food by substances migrating from a direct-contact plastic layer: Assessment using a generic quantitative household scale methodology. Food Additives and Contaminants 24(1), 75-94.

Wagner, M. and Oehlmann, J., 2010. Endocrine disruptors in bottled mineral water:

Estrogenic activity in the E-Screen. Journal of Steroid Biochemistry and Molecular Biology (in Press).

Wagner, M. and Oehlmann, J., 2009. Endocrine disruptors in bottled mineral water: Total estrogenic burden and migration from plastic bottles. Environmental Science and Pollution Research 16(3), 278-286.

Wegelin, M., Canonica, S., Alder, C., Marazuela, D., Suter, M.J.F., Bucheli, T.D., Haefliger, O.P., Zenobi, R., McGuigan, K.G., Kelly, M.T., Ibrahim, P. and Larroque, M., 2001. Does sunlight change the material and content of polyethylene terephthalate (pet) bottles? Journal of Water Supply: Research and Technology - AQUA 50(3), 125-133.

Welle, F. and Franz, R., 2011. Migration of antimony from PET bottles into beverages: Determination of the activation energy of diffusion and migration modelling compared with literature data. Food Additives and Contaminants - Part A Chemistry, Analysis, Control, Exposure and Risk Assessment 28(1), 115-126.

Welle, F. and Franz, R., 2008. $\mathrm{SiO}_{\mathrm{x}}$ layer as functional barrier in polyethylene terephthalate (PET) bottles against potential contaminants from post-consumer recycled PET. Food Additives \& Contaminants: Part A: Chemistry, Analysis, Control, Exposure \& Risk Assessment 25(6), 788 - 794.

Westerhoff, P., Prapaipong, P., Shock, E. and Hillaireau, A., 2008. Antimony leaching from polyethylene terephthalate (PET) plastic used for bottled drinking water. Water Research $42(3), 551-556$.

Widén, H., Leufvén, A. and Nielsen, T., 2004. Migration of model contaminants from PET bottles: influence of temperature, food simulant and functional barrier. Food Additives and Contaminants 21(10), 993 - 1006. 
Xie, Z., Selzer, J., Ebinghaus, R., Caba, A. and Ruck, W., 2006. Development and validation of a method for the determination of trace alkylphenols and phthalates in the atmosphere. Analytica Chimica Acta 565(2), 198-207.

Yang, C.Z., Yaniger, S.I., Jordan, V.C., Klein, D.J. and Bittner, G.D., 2011. Most Plastic Products Release Estrogenic Chemicals: A Potential Health Problem That Can Be Solved. Environ Health Perspect 119(7), 982-996.

Zhang, H. and Ward, I.M., 1995. Kinetics of hydrolytic degradation of poly(ethylene naphtalene-2,6-dicarboxylate). Macromolecules 28(23), 7622-7629.

Zih-Perényi, K., Jankovics, P., Sugar, E. and A., L., 2008. Solid phase chelating and separation of inorganic antimony species in pharmaceutical and water samples for graphite furnace atomic absorption spectrometry. Spectrochimica Acta Part B 63, 445-449.

Zimmerman, H., 1977. Degradation and Stabilisation of Polyesters, Applied Science Publishers, London (UK), pp. 79-119.

Zweifel, H., 2001. Handbook of Plastic Additives, 5th Ed., Verlag, C.H. Beck Publishers, Munich (Allemagne). 


\begin{tabular}{|c|c|c|c|c|c|c|}
\hline $\begin{array}{l}\text { Exposure } \\
\text { temperature } \\
\left({ }^{\circ} \mathrm{C}\right)\end{array}$ & $\begin{array}{l}\text { Exposure } \\
\text { conditions }\end{array}$ & Simulant & $\begin{array}{l}\text { Other } \\
\text { parameters }\end{array}$ & $\begin{array}{l}\text { Concentration } \\
\text { mean } \\
(\mu \mathrm{g} / \mathrm{L})\end{array}$ & $\begin{array}{l}\text { Concentration } \\
\text { range } \\
(\mu \mathrm{g} / \mathrm{L})\end{array}$ & References \\
\hline Refrigerated & $24 \mathrm{~h}$, darkness & Ultrapure water & - & - & $0.846 \pm 1.652$ & Cheng et al. (2010) \\
\hline Refrigerated & 37 days & Groundwater & - & - & $0.05 \pm 0.017$ & Shotyk et al. (2006) \\
\hline Refrigerated $\left(2^{\circ} \mathrm{C}\right)$ & 150 days & Ultrapure water, $\mathrm{pH}=6.5$ & Water bottled in hard PET & 0.003 & - & Reimann et al. (2010) \\
\hline Refrigerated $\left(2^{\circ} \mathrm{C}\right)$ & 150 days & Ultrapure water, $\mathrm{pH}=6.5$ & Water bottled in soft PET & 0.025 & - & Reimann et al. (2010) \\
\hline Refrigerated $\left(2^{\circ} \mathrm{C}\right)$ & 150 days & Ultrapure water, $\mathrm{pH}=3.5$ & Water bottled in hard PET & 0.0085 & - & Reimann et al. (2010) \\
\hline Refrigerated $\left(2^{\circ} \mathrm{C}\right)$ & 150 days & Ultrapure water, $\mathrm{pH}=3.5$ & Water bottled in soft PET & 0.027 & - & Reimann et al. (2010) \\
\hline r.t. & $24 \mathrm{~h}$, darkness & Ultrapure water at $100^{\circ} \mathrm{C}$ & - & - & $3.243-1.652$ & Cheng et al. (2010) \\
\hline r.t. & $24 \mathrm{~h}$ & Microwave heated ultrapure water & - & - & $0.391-10.51$ & Cheng et al. (2010) \\
\hline r.t & 6 months & Groundwater & - & 0.566 & - & Shotyk et al. (2006) \\
\hline r.t. & 7 days, darkness & Ultrapure water at $\mathrm{pH}=4$ & - & - & $<0.02-3.794$ & Cheng et al. (2010) \\
\hline $22^{\circ} \mathrm{C}$ & 3 months & Commercial water & - & $0.226 \pm 0.160$ & - & $\begin{array}{l}\text { Westerhoff et al. } \\
(2008)\end{array}$ \\
\hline $22^{\circ} \mathrm{C}$ & $<1$ year & Still mineral water & - & $0.26 \pm 0.160$ & - & Keresztes et al. (2009) \\
\hline $22^{\circ} \mathrm{C}$ & $<1$ year & Sparkling mineral water & - & $0.40 \pm 0.22$ & - & Keresztes et al. (2009) \\
\hline $40^{\circ} \mathrm{C}$ & 10 days & Aqueous simulant & - & - & $<0.03$ & Nishioka et al. (2002) \\
\hline $80^{\circ} \mathrm{C}$ & 7 days & Commercial water & - & - & 14.4 & $\begin{array}{l}\text { Westerhoff et al. } \\
(2008)\end{array}$ \\
\hline- & 7 days, sunlight & Ultrapure water & - & - & $<0.02-4.611$ & Cheng et al. (2010) \\
\hline- & 7 days, in-car storage & Ultrapure water & - & - & $<0.02-3.08$ & Cheng et al. (2010) \\
\hline
\end{tabular}




\begin{tabular}{|c|c|c|c|c|c|c|c|}
\hline $\begin{array}{l}\text { Compound } \\
\text { Name }\end{array}$ & Simulant & $\begin{array}{l}\text { Exposure } \\
\text { temperature }\end{array}$ & $\begin{array}{l}\text { Exposure } \\
\text { conditions }\end{array}$ & $\begin{array}{l}\text { Other } \\
\text { parameters }\end{array}$ & $\begin{array}{l}\text { Concentration } \\
\text { range }(\mu \mathrm{g} / \mathrm{L})\end{array}$ & $\begin{array}{l}\text { Concentration } \\
\text { mean }(\mu \mathrm{g} / \mathrm{L})\end{array}$ & References \\
\hline \multirow[t]{11}{*}{ Formaldehyde } & Mineral water & - & - & - & $<0.5-59$ & - & Sugaya et al. (2001) \\
\hline & Still water & - & - & Total organic carbon & $2.2-64.6$ & - & Nawrocki et al. (2002) \\
\hline & Still water & - & - & $<2.0-2.9 \mu \mathrm{g} / \mathrm{g}$ in PET & $<5.0-27.9$ & - & Mutsuga et al. (2006) \\
\hline & Still water & r.t. & 6 days & - & - & $7.1 \pm 0.7$ & Dabrowska et al. (2003) \\
\hline & Still mineral water & - & 63 days, sunlight & - & - & 44 & Wegelin et al. (2001) \\
\hline & Still mineral water & - & 126 days, sunlight & - & - & 1 & Wegelin et al. (2001) \\
\hline & Carbonated water & r.t. & 170 days & - & - & $60.0 \pm 6.0$ & Dabrowska et al. (2003) \\
\hline & Carbonated water at $\mathrm{pH}=4.5$ & r.t. & 6 days & - & - & $10.5 \pm 1.1$ & Dabrowska et al. (2003) \\
\hline & Carbonated water & - & - & TOC & $24.6-96.1$ & - & Nawrocki et al. (2002) \\
\hline & Carbonated water & - & - & $<0.5-0.9 \mu \mathrm{g} / \mathrm{g}$ in PET & $<5.0-13.7$ & - & Mutsuga et al. (2006) \\
\hline & Carbonated water & - & - & - & - & $1.4 \pm 0.1$ & Mutsuga et al. (2006) \\
\hline \multirow{18}{*}{ Acetaldehyde } & Mineral water & - & - & - & $<0.5-59$ & - & Sugaya et al. (2001) \\
\hline & Mineral water & - & - & - & $<0.5-260$ & - & Sugaya et al. (2001) \\
\hline & Mineral water & - & - & - & $<0.5-0.9$ & - & Sugaya et al. (2001) \\
\hline & Mineral water & - & - & - & $<0.5-0.3$ & - & Sugaya et al. (2001) \\
\hline & Still water & - & - & TOC & $0.9-133.8$ & - & Nawrocki et al. (2002) \\
\hline & Still water & - & - & $<2.0-2.9 \mu \mathrm{g} / \mathrm{g}$ in PET & $<5.0-107.8$ & - & Mutsuga et al. (2006) \\
\hline & Still water & r.t. & 6 days & - & - & $4.8 \pm 0.5$ & Dabrowska et al. (2003) \\
\hline & Still mineral water & - & 63 days, sunlight & - & - & 3 & Wegelin et al. (2001) \\
\hline & Still mineral water & - & 126 days, sunlight & - & - & 2 & Wegelin et al. (2001) \\
\hline & Still mineral water & $40^{\circ} \mathrm{C}$ & 10 days & - & $<2$ & - & Ceretti et al. (2010) \\
\hline & Carbonated water & - & - & TOC & $4.7-317.8$ & - & Nawrocki et al. (2002) \\
\hline & Carbonated water & - & - & $0.5-0.9 \mu \mathrm{g} / \mathrm{g}$ in PET & $<5.0-46.9$ & - & Mutsuga et al. (2006) \\
\hline & Carbonated water at $\mathrm{pH}=4.5$ & r.t. & 6 days & - & - & $24.6 \pm 2.5$ & Dabrowska et al. (2003) \\
\hline & Carbonated water & r.t. & 170 days & - & - & $78.1 \pm 7.8$ & Dabrowska et al. (2003) \\
\hline & Carbonated water & r.t. & 5 weeks & $\mathrm{CO}_{2}$ content: $3.88 \mathrm{~g} / \mathrm{L}$ & - & $28.0 \pm 2.8$ & Dabrowska et al. (2003) \\
\hline & Carbonated water & r.t. & 5 weeks & $\mathrm{CO}_{2}$ content: $4.53 \mathrm{~g} / \mathrm{L}$ & - & $52.0 \pm 5.2$ & Dabrowska et al. (2003) \\
\hline & Carbonated water & r.t. & 5 weeks & $\mathrm{CO}_{2}$ content: $6.40 \mathrm{~g} / \mathrm{L}$ & - & $79.0 \pm 7.9$ & Dabrowska et al. (2003) \\
\hline & Carbonated water & $40^{\circ} \mathrm{C}$ & 10 days & - & $<2$ & - & Ceretti et al. (2010) \\
\hline
\end{tabular}

r.t : room temperature ; TOC :Total Organic Carbon; n.d.: not detected. 


\begin{tabular}{|c|c|c|c|c|c|c|c|}
\hline $\begin{array}{l}\text { Compound } \\
\text { Name }\end{array}$ & Simulant & $\begin{array}{l}\text { Exposure } \\
\text { temperature }\end{array}$ & $\begin{array}{l}\text { Exposure } \\
\text { conditions }\end{array}$ & $\begin{array}{l}\text { Other } \\
\text { parameters }\end{array}$ & $\begin{array}{l}\text { Concentration } \\
\text { range }(\mu \mathrm{g} / \mathrm{L})\end{array}$ & $\begin{array}{l}\text { Concentration } \\
\text { mean }(\mu \mathrm{g} / \mathrm{L})\end{array}$ & References \\
\hline \multirow[t]{2}{*}{ Propanal } & Mineral water & - & - & - & $<0.5-0.9$ & - & Sugaya et al.(2001) \\
\hline & Carbonated water & - & - & - & - & $<0.05$ & Dabrowska et al. (2003) \\
\hline Butanal & Mineral Water & - & - & - & $<0.5-0.3$ & - & Sugaya et al. (2001) \\
\hline \multirow[t]{3}{*}{ Nonanal } & Still water & - & - & TOC & $0.9-11.3$ & - & Nawrocki et al. (2002) \\
\hline & Carbonated water & - & - & TOC & $0.95-7.9$ & - & Nawrocki et al. (2002) \\
\hline & Carbonated water & - & - & - & - & $<0.05$ & Dabrowska et al. (2003) \\
\hline \multirow[t]{3}{*}{ Glyoxal } & Still water & - & - & TOC & - & 5.9 & Nawrocki et al. (2002) \\
\hline & Carbonated water & - & - & TOC & - & 0.9 & Nawrocki et al. (2002) \\
\hline & Carbonated water & - & - & - & - & $<0.05$ & Dabrowska et al. (2003) \\
\hline \multirow[t]{2}{*}{ Methylglyoxal } & Still water & - & - & TOC & $0.9-15.8$ & - & Sugaya et al. (2001) \\
\hline & Carbonated water & - & - & TOC & $0.8-4.6$ & - & Sugaya et al. (2001) \\
\hline \multirow[t]{2}{*}{ Acetone } & Still water & - & - & TOC & $5.1-107.6$ & - & Nawrocki et al. (2002) \\
\hline & Carbonated water & - & - & TOC & $16.8-125.6$ & - & Nawrocki et al. (2002) \\
\hline
\end{tabular}

r.t : room temperature ; TOC :Total Organic Carbon; n.d.: not detected. 


\begin{tabular}{|c|c|c|c|c|c|c|}
\hline $\begin{array}{l}\text { Compound } \\
\text { name }\end{array}$ & Simulant & $\begin{array}{l}\text { Exposure } \\
\text { temperature }\end{array}$ & $\begin{array}{l}\text { Exposure } \\
\text { conditions } \\
\end{array}$ & $\begin{array}{l}\text { Concentration } \\
\text { range }(\mu \mathrm{g} / \mathrm{L})\end{array}$ & $\begin{array}{l}\text { Concentration } \\
\text { mean }(\mu \mathrm{g} / \mathrm{L}) \\
\end{array}$ & References \\
\hline \multirow[t]{2}{*}{ DMP } & Mineral water & $22^{\circ} \mathrm{C}$ & 30 days & $<0.04$ & - & Bosnir et al. (2007) \\
\hline & Water & $\mathrm{Up}$ to $30^{\circ} \mathrm{C}$ & 10 weeks & $<0.002-0.003$ & 0.002 & Casajuana and Lacorte (2003) \\
\hline \multirow[t]{2}{*}{ DEP } & Mineral water & $22^{\circ} \mathrm{C}$ & 30 days & $<0.04-1$ & 0.11 & Bosnir et al. (2007) \\
\hline & Water & $\mathrm{Up}$ to $30^{\circ} \mathrm{C}$ & 10 weeks & $0.082-0.355$ & 0.214 & Casajuana et Lacorte (2003) \\
\hline \multirow[t]{3}{*}{ DBP } & Still water & Refrigerated & - & $0.08-0.32$ & $0.357 \pm 0.606$ & Cao (2008) \\
\hline & Mineral water & $22^{\circ} \mathrm{C}$ & 30 days & $<0.04-50$ & 11 & Bosnir et al. (2007) \\
\hline & Water & $\mathrm{Up}$ to $30^{\circ} \mathrm{C}$ & 10 weeks & $0.020-0.070$ & 0.046 & Casajuana and Lacorte (2003) \\
\hline \multirow[t]{2}{*}{ DiBP } & Mineral water & $22^{\circ} \mathrm{C}$ & 30 days & $<0.005$ & - & Bosnir et al. (2007) \\
\hline & Water & $\mathrm{Up}$ to $30^{\circ} \mathrm{C}$ & 10 weeks & $<0.004-0.010$ & $<0.004$ & Casajuana and Lacorte (2003) \\
\hline \multirow[t]{8}{*}{ DEHP } & Dionised water & r.t. & 17 hours, darkness & $0.14-0.24$ & $0.19 \pm 0.05$ & Schmid et al. (2008) \\
\hline & Dionised water & r.t. & 17 hour, sunlight & $0.10-0.38$ & $0.26 \pm 0.10$ & Schmid et al. (2008) \\
\hline & Dionised water & $60^{\circ} \mathrm{C}$ & 17 hours, sunlight & $0.15-0.71$ & $0.36 \pm 0.21$ & Schmid et al. (2008) \\
\hline & Mineral water & r.t. & 12 months, darkness & - & $3220 \pm 200$ & Biscardi et al. (2003) \\
\hline & Mineral water & r.t. & 3 months & $<0.02-6.8$ & - & Leivadara et al. (2008) \\
\hline & Mineral water & $22^{\circ} \mathrm{C}$ & 30 days & $<0.04-50$ & 8.8 & Bosnir et al. (2007) \\
\hline & Water & $\mathrm{Up}$ to $30^{\circ} \mathrm{C}$ & 10 weeks & $<0.002-0.188$ & 134 & Casajuana and Lacorte (2003) \\
\hline & Mineral water & $\mathrm{Up}$ to $30^{\circ} \mathrm{C}$ & 3 months, sunlight & $<0.02$ & - & Leivadara et al. (2008) \\
\hline DOP & Mineral water & $22^{\circ} \mathrm{C}$ & 30 days & $<0.04$ & - & Bosnir et al. (2007) \\
\hline
\end{tabular}

Dioctyl phthalate; r.t.: room temperature. 